Food security from free collection of foods Evidence from India

Sudha Narayanan

Indira Gandhi Institute of Development Research, Mumbai December 2019 


\title{
Food security from free collection of foods Evidence from India
}

\author{
Sudha Narayanan
}

Email(corresponding author): sudha@igidr.ac.in

\begin{abstract}
Despite recognition of the role of free collection of foods in forwarding nutritional security, there is only limited systematic research on its importance and role. This paper provides the first estimates for India, of the extent to which households depend on free collection of foods and examines its association with dietary adequacy and quality. In 2011-12 around 5.8\% of all Indian households collected foods free, with some households collecting more than ten distinct food types in a month. For these households, free collection comprised, on average, $4.5 \%$ of the total value of food consumption, going upto $15 \%$ for a tenth of them. Using a pooled cross-section from 2009-10 and 2011-12 of nationally representative household level consumption data that identifies the source of food, this paper uses an instrumental variable approach to estimate the association between free collection of foods and dietary adequacy and quality. The paper finds that the probabiity of having more than two meals increases when households access free foods and there is robust evidence of higher dietary diversity (77\% to four-fold), driven by specific food groups such as vegetables, meats, fish and green leafy vegetables. The findings of this paper point to a need to mainstream discussions of sources of food other than farm, market and state, recognizing explicitly the role of free collection in improving dietary adequacy and quality.
\end{abstract}

Keywords: food environment, free collection, common pool resources, food security, dietary quality, India

JEL Code: Q18, Q2, L73, D12 


\title{
Food security from free collection of foods
}

\author{
Evidence from India
}

\section{Sudha Narayanan ${ }^{l}$}

\begin{abstract}
Despite recognition of the role of free collection of foods in forwarding nutritional security, there is only limited systematic research on its importance and role. This paper provides the first estimates for India, of the extent to which households depend on free collection of foods and examines its association with dietary adequacy and quality. In 2011-12 around 5.8\% of all Indian households collected foods free, with some households collecting more than ten distinct food types in a month. For these households, free collection comprised, on average, $4.5 \%$ of the total value of food consumption, going upto $15 \%$ for a tenth of them. Using a pooled cross-section from 2009-10 and 2011-12 of nationally representative household level consumption data that identifies the source of food, this paper uses an instrumental variable approach to estimate the association between free collection of foods and dietary adequacy and quality. The paper finds that the probabiity of having more than two meals increases when households access free foods and there is robust evidence of higher dietary diversity (77\% to four-fold), driven by specific food groups such as vegetables, meats, fish and green leafy vegetables. The findings of this paper point to a need to mainstream discussions of sources of food other than farm, market and state, recognizing explicitly the role of free collection in improving dietary adequacy and quality.
\end{abstract}

Keywords: food environment, free collection, common pool resources, food security, dietary quality, India.

\section{JEL Code: Q18, Q2, L73, D12}

\footnotetext{
${ }^{1}$ Sudha Narayanan is Associate Professor, Indira Gandhi Institute of Development Research (IGIDR), Mumbai. Email: sudha@igidr.ac.in. Acknowledgements: I thank Shree Saha for excellent research assistance.
} 


\section{Food security from free collection of foods \\ Evidence from India}

\section{Introduction}

The growing literature on food environments acknowledges explicitly the role of free collection of foods in ensuring food security (Powell, et al., 2015; Turner et al., 2019; Rowland et al., 2017; Bharucha \& Pretty, 2010, Vira et al., 2015; FAO 2017; Vinceti et al., 2013; Pimentel et al., 1997). Free collection of foods is most commonly thought of as collection from common pool resources (CPR), communal lands and water bodies and is regarded as distinct from food acquired through charity, gifts and exhange and other informal arrangments between people, including sharing and some forms of gleaning. Although there has been extensive research on the role of natural resources, especially of CPRs in supporting livelihoods and incomes from sale of collected produce, fodder and fuel, it's direct role as a source of diverse types of food remained surprisingly underresearched until recently (See Powell et al., 2015 for a detailed review of studies).

Several small-scale studies have established that those who have access to forests or tree cover and collect foods have more diverse diets (Powell et al., 2011 for Tanzania; Johnson et al., 2013, for Malawi). Just as higher forest cover is associated with higher consumption of Vitamin-A rich foods, net forest loss is associated with decreased dietary diversity (Johnson et al., 2013). Multi-country studies using larger surveys too establish a positive association between tree cover and dietary diversity of children as well as consumption of fruits and vegetables. (Ickowitz et al 2014, on 21 African countries). Some studies establish a link between bushmeat and anemia, finding for example that, in Madagascar, the absence of bushmeat is associated with a $29 \%$ higher prevalence of anemia amongst children (Golden, et al., 2011). Termote et al. (2012) find in Democratic Republic of Congo that wild edible plants contribute significantly to better diets, but is not used to the 
extent it can to forward nutritional security. Free collection need not be associated with forests alone and studies of indigenous communities, such as the Inuits in Canada, often distinguish freely collected food based on the source, for example, sea food, sky food and land foods (see Hopping, et al. 2010, for example). Uncultivated foods can also be sourced from farm/agricultural lands. Ickowitz et al. (2016), for example, notes that in Indonesia those cultivators practicing swidden agriculture tend to have a micronutrient rich diet. Powell et al. (2011) note that wild foods from agricultural land are more important than from forests in Tanzania. Some households that manage tea plantations in Yunnan province in south-western China routinely incorporate as many as 150 wild foods from their surroundings into their diets (Ahmed et al., 2013).

The importance of water bodies and grasslands in contributing food and nutrition security is less studied relative to forests as sources of food, although their importance is well recognized (Bene \& Heck, 2005; Belton \& Thilsted, 2014, Jodha,1986, 1990 for Indian grasslands.) In the context of fish for food security, the consequences of overexploitation of water resources and climate change has attracted considerable attention (Godfray et al., 2014; Pearce et al., 2010) although there are fewer recent studies that examine its links with diets or nutritional status (Powell et al., 2015; Hopping, et al., 2010).

Further, studies emphasize that free collection is restricted neither to rural settings nor to developing countries. For example, in rainforest cities, free collection is significant and ignoring high levels of non-retail sourcing can lead to an overestimate of food insecurity (Davies, et al, 2017; Turner et al., 2019). In developed countries, Byker Shanks et al. (2015) note, for example, that rural and indigenous communities in Montana, USA, rely on hunting and harvesting wild edible plants such as berries for health benefits, while maintaining community traditions and practices. In Canada, the Inuit communities' dependence on natural resources for their diets and the crowding out of traditional diets by non-nutrient dense, junk foods (Hopping, et al, 2010, for example). 
Given the growing evidence worldwide, it is surprising that free collection of foods, especially from CPRs, does not find a more prominent place in the broader context of food policy (Ahmed and Herforth, 2017; Herforth and Ahmed, 2015). For example, policy interventions that target supply constraints have overwhelmingly focussed on agricultural production; alternatively, the focus is on distribution via safety nets and income transfers or on the ability of markets to provide diverse and affordable foods. Policy discussions on sources of food other than farm and market have remained largely peripheral. Commentators argue that this is likely due to the fact that communities that depend on free collection are marginalized from policy making processes, doubly so because women, rather than men, tend to be the main providers of such food (Bromley, 1992; Beck, 1994). The neglect could also be due to data gaps. Paucity of national-scale data make it harder to ascertain and understand the role of freely sourced foods at the macro-level. Ahmed and Herforth (2017) point out that the absence of appropriate metrics could be another reason for relative neglect of free collection. ${ }^{2}$ This is despite the rich literature on natural resources management and CPRs that have long emphasized their role in supporting food and nutritional security.

This blind spot in policy is apparent in discssions of India's food security as well. Food policy interventions to address food security in India focus mainly on the distributive aspects emanating from constraints to access and affordability or to alleviating production constraints (Pingali, et al., 2019). Important as these are, the role of free collection of wild edible and uncultivated foods remains largely unackowledged in policy documents. The National Food Security Act (NFSA), 2013, for example, makes no mention of either CPRsourced foods or free collection in general nor of rights associated with access to commons. Yet, free collection could be potentially crucial to poor households. As of 2011-12, as much as 60 per cent of the monthly per capita expenditure of rural and urban households was on

\footnotetext{
${ }^{2}$ They point out the potential for representing the contribution of biodiversity to sustainable diets is being developed by ecologists, an example being the Nutritional Functional Diversity score (Luckett et al. 2015).
} 
food (NSSO, 2013). Studies in India document diets that include a large variety of uncultivated foods (as many as 121 different kinds in a span of six months), sometimes accounting for between 12 and $24.4 \%$ of total cooked food of households (Deb, et al, 2014). ${ }^{3}$ There is some evidence from India that dependence on free collection of uncultivated foods from the commons is higher in the drought prone areas (Iyengar, 1989; Iyangar \& Shukla, 2002) and such collection acts as safety nets during lean seasons (Chopra \& Dasgupta, 2008).

This paper aims to contribute to existing research that evaluates the role of free collection of foods in augmenting household food and nutrition security. I draw on nationally representative consumption survey data from India, in 2009-10 and 2011-12 from rural and urban areas, that captures the source of foods consumed over a one-month recall period. This paper provides the first estimates of the role of free collection of foods in India and documents the extent, patterns and diversity of foods sourced. The main research effort is to uncover the association between free collection of food and dietary quality and adequacy. The paper focusses specifically on aspects of household level dietary diversity. At the individual level, it focusses on the number of meals an individual has on a typical day.

Since those who collect uncultivated foods might be systematically different from those who don't and because the decision to procure foods from different sources is likely simultaneous, I use an instrumental variable approach to address this endogeneity. Specifically, I take advantage of an exogenous variation in the survey date which is correlated with the presence and availability of uncultivated foods while accounting for other correlated confounders, elaborated later in the paper. I use the Normalized Density of Vegetation Index (NDVI) during the month preceding the interview as an instrument for whether or not the household collects food, with appropriate additional controls that strengthen the exclusion restriction. This approach helps identify treatment effects for those who, on account of the

\footnotetext{
${ }^{3}$ Uncultivated foods consumed weighed $0.45 \mathrm{kgs}$ to $1.19 \mathrm{kgs}$ per day on an average. On an average, $4.56 \mathrm{~kg}$ of such foods were harvested per household, during each collection foray. (Deb, et al., 2014)
} 
expansion in availability of vegetation, are prompted to rely on free collection of foods. I find robust evidence that households that collect food have better dietary quality relative to what they would have had they not accessed freely available food. The Household Dietary Diversity Score (HDDS) is higher by $77 \%$ to upto 3 times, driven by the inclusion of green leafy vegetables (GLV), fish, meats and eggs and other vegetables. Although free collection does not increase the probability of an individual having at least two meals a day, it does have a strong impact of the individual having three or more meals a day. Alternate empirical strategies, including using alternate instruments, matching techniques and triple/quadruple differences generate a range of estimates that vary in degree, but not in direction or statistical significance. Several robustness checks support these results. Overall, these constitute persuasive evidence of the critical role of free collection and make a case for providing explicit attention to the role of free collection in the design and study of food environments and food policy.

This paper is divided into seven parts. Following this, I discuss the sources of data and empirical strategy (Sections 2 and 3, respectively). Threafter, Section 4 documents the patterns of consumption of freely sourced foods. Section 5 estimates the role of free foods in augmenting nutritional outcomes. Section 6 checks for robustness of the findings and Section 7 concludes the discusion.

\section{Data}

Of the rich sources of data available in India, the National Sample Surveys (NSS) provide the most comprehensive data on consumption expenditures and quantities of households, covering as many as 151 food and non-food items. These form the basis for estimating poverty in India. Although the NSS Surveys on Consumer Expenditure take place annually, the quinquennial rounds are thicker rounds that cover a larger sample size and are representative at the district level. I use two 'thick' rounds of the NSS for this paper, the $66^{\text {th }}$ and $68^{\text {th }}$ rounds, conducted in July 2009-June 2010 and July 2011- June 2012, respectively, 
for a pooled cross-section dataset. Fortuitously, the $68^{\text {th }}$ Round was to have been a thin round but was implemented instead as a thick round, allowing combining two rounds that are close enough to each other in time, so that secular trends are not a concern.

These surveys collect information on the source, quantity and value of consumption at the household level, for a a recall period of 30 days. The surveys capture individual items in different food groups. Since the purpose of this paper is in part to examine the role of free collection in improving dietary quality, I map these food groups to categories that constitute the Household Dietary Diversity Score (HDDS). While an exact mapping is not possible because of data limitations, we identify the following categories of foods, twelve in all. These include Cereals and cereal substitutes, Pulses (and pulse products), Sugar, salt and spices, Edible oils, Meats, Vegetables (other than green leafy vegetables), Roots and Tubers, Fruits, Milk, Egg, Fish and Green Leafy Vegetables.

The survey identifies seven mutually exclusive sources of foods - only purchase, only home-grown, both purchase and home-grown, only free collection, only exchange of goods and services, only gifts/charities and others. The category 'others' is used if respondent households have multiple sources or name sources that do not fall under these categories. ${ }^{4}$ In this paper, free collection is treated as the category of interest. The source remains unidentified in the survey and we therefore do not know explicitly whether they came from the commons, from farmlands and so on. Further, it is possible that some freely collected items could be reported under 'others', but since this category does not appear widely in the data, the extent to which we underestimate free collection is not very serious. In exploring the source of foods, this paper uses the NSS data in a novel way.

As outcome variables, I focus on specific aspects of food security. The first is the probability that an individual has two or three square meals a day, reflecting food adequacy in a coarse sense. If free collection of foods enables access at a very basic level, it could

\footnotetext{
${ }^{4}$ Schedule 1.0 and Instructions to the Enumerators for these surveys contain further details.
} 
translate into fewer individuals going hungry or missing a meal or be associated with a lower likelihood of an individual having adequate number of meals. The survey asks of each household member, the "number of meals usually taken in a day" 5,6

A second aspect is the diversity of food groups consumed in the month preceding the survey. I operationalize this through a Household Dietary Diversity Score (HDDS) composed of 12 food groups, following the methods prescribed in FAO \& FANTA(2007). This overlooks intrahousehold allocation issues that are admittedly crucial, especially from a gender perspective and this remains a limitation of this study (see Lentz, et al., 2019 for example). The number of meals is indeed captured at the individual level, but with limited data at the individual level, intrahousehold allocation issues cannot be explored rigorously even in this case.

Within these 12 food groups, I also construct diversity scores specific to each food group and a binary variable for whether or not a household has consumed a particular food group - differentiating diversity on the intensive and extensive margins. A key feature of uncultivated foods that are freely collected is their large diversity. Studies in India, for example, have documented 30 kinds of mushrooms and as many as 26 varieties of greens, 23 types of tubers, 28 types of small meats within a given cluster of villages (Deb, et al, 2014). While the survey does not capture varieties in detail, we are interested in examining broadly the food groups that are more likely to be incorporated in diets on account of free collection.

\footnotetext{
${ }^{5}$ NSS KI(66/1.0): Key Indicators of Household Consumer Expenditure in India, 2009-10, D-27.

${ }^{6}$ As per the survey a meal is "composed of one or more readily eatable (generally cooked) items of food, the usually major constituent of which is cereals. The meals consumed by a person twice or thrice a day provide him/her the required energy (calorie) and other nutrients for living and for pursuing his/her normal avocations." Even in the absence of cereals, the key is that quantities consumed should be substantive, Instructions to Field Staff, Vol. I: NSS 66th Round 3.4.9
} 
Ideally, we would want to go beyond diversity scores to nutritient intakes that consumption implies (as for example, Msuya, et al., 2009; Bodecker et al., 2014). However, given the vast diversity in types of foods consumed, even within a village, there is wide variation in the nutritional content of each of these. For example, greens (GLVs) can differ in nutritient content by a factor of 11-20 times for calcium, carotene and iron, even within a cluster of villages in the same state as do different types of fish (Deb et al., 2014; Belton \& Thilsted, 2014). Conversion of these quantities to nutrients would therefore result in large measurement errors. Quantities consumed are themselves likely measured with error, considering that these are recall data. The preferred approach in this paper is therefore to rely on dietary diversity scores.

The key 'causal' variable of interest is whether a household engages in free collection of food. I construct a variable that takes the value 1 if the households has mentioned free collection as the source for any food item that the household consumed in the past 30 days. The aim is then to see if this group of households on average have dietary adequacy, i.e. whether an individual in such a household gets more than 2 (or 3) meals a day, and better diet quality (represented by HDDS) than they would have in the absence of free collection.

\section{Estimation Strategy}

Uncovering the association between free collection of foods and dietary diversity is empirically challenging because the decision to collect and consume uncultivated foods or wild edible plants is endogenous. To some extent, if the poor and marginalized are more likely to rely on free collection and are also likely to have poorer dietary quality, ignoring this would lead one to underestimate the association between free collection and dietary diversity. This is less of an issue since this would then be a conservative estimate of the role of free collection. If, however, the non-poor or relatively better off households have better access to the commons or other food resources, and are anyway likely to have more dietary diversity, ignoring this would lead us to overestimate the relationship. This is just one example of the potential bias on account of selection. Further, the decision to collect food depends on a wide 
range of complex factors that include food production and agricultural performance, market access and prices and the availability of such uncultivated foods. It is likely that these decisions are made jointly rather than sequentially or independently of one another, again leading to possible identification problems on account of simultaneity.

In this paper, I address potential endogeneity via an instrumental variable approach. In the NSS Survey, which spans a year (July to June of the following year), the sample is randomly allocated across four rounds or quarters. ${ }^{7}$ I take advantage of this exogenous variation in the timing of the interview to identify those that were interviewed when the availability of vegetation is low versus those interviewed when such availability of vegetation is higher, implying an exogenous temporal increase (decrease) in vegetation. Since on a given day, households across the country might be interviewed, there is also spatial variation in the availability of vegetation. The availability of vegetation is proxied by the Normalized Density of Vegetation Index (NDVI), measured at the district level for a month preceding the day of the interview, representing levels of supply of sources for free collection (See Appendix A, Supplementary Materials for details).

Being interviewed when NDVI is high or low also correlates, however, with the likelihood of sourcing food elsewhere, such as own production or markets, since these too exhibit strong seasonality in India. To strengthen the exclusion restriction, therefore, it is important to control for variables that represent sources of variation in other sources of food, such as own production, markets and other forms of gift, trade and exchange. I control for the the share of food sourced by the household from different means. I also identify proxies that are more defensible as exogenous inflencers of these other sources of foods. I control, for example, for whether or not, the survey was conducted in the Lean season (Lean). I define the months of July to October as the lean season, until the monsoon crop is harvested in October,

\footnotetext{
${ }^{7}$ The NSS Survey documents note that both rural and urban samples are drawn as two independent sub-samples and equal numbers have been allocated among the four sub rounds.
} 
based both on on existing work on seasonal hunger (Deb, et al., 2014; Sarangi et al, 2016). In India, which is predominantly rainfed, the main agricultural season runs from June to October-November (called kharif), when the monsoon feeds the crop. A majority of rain falls in this period and in most rainfed areas this is the only season when cultivation takes place. November to February (called rabi) is the winter cultivating season and only a fraction of all arable land is cultivated in the winter season. Usually kharif is a vulnerable season because at that time, producers who grow a single crop each year, tend to run low on stocks from own production and markets too may offer limited variety. This is therefore regarded the lean season.

Further, since the NDVI could equally capture on-farm vegetation, I include other temperature and rainfall. For temperature, I use three variables: Growing Degree Days (GDD) - or the cumulative exposure of a crop to temperature. Also included are the number of days in the main cropping season that temperature exceeding the maximum thershold and the number of days the temperature falls below the minimum threshold for optimal yields. This is computed for the most important crop in the district over the decade ending in 2011-12. Each of these has a strong relationship to plant physiological growth and yields and serve as proxies for shocks to supply of food from agriculture (Harou et al, 2017; Lobell, et al., 2012). For these measures, we follow the approach in Narayanan, et al (2017), who construct these estimates for India at the district level. In addition, I include use rainfall shocks $(R F)$, measuring separately positive and negative deviations in rainfall from month-means over a span of a decade, expressed in standard deviation units. Like the variables on temperature these too are captured at the district level. Appendix A (Supplementary Materials) provides the details of the computation. It turns out that the variables representing temperature, NDVI and rainfall are not highly correlated with one another (for example, NDVI and number of days temperature was higher than the maximum threshold was -0.36).

Apart from this, I also include the district-level share of food consumption sourced from markets and a district food price index, in addition to actual shares of the household's 
food consumption derived from other sources such as markets and own production. ${ }^{8}$ The inclusion of these variables contributes to strengthening the exclusion restriction, so that the NDVI more credibly influences dietary diversity only via availability of uncultivated foods and not via agricultural supply or markets. With this basic framework, the main research questions center on estimating the following models:

$$
\begin{aligned}
& \ln \left(H D D S_{h d r}\right)=\alpha_{0}+\alpha_{1} F_{h d r}+\alpha_{2} H_{h d r}+\alpha_{3} \text { Lean }_{d r}+\alpha_{4} \sum_{j=1}^{3} \text { Temp }_{j h d}+\alpha_{5} \sum_{k=1}^{2} R F_{k h d r} \\
& +\alpha_{6} \text { Rural }_{h d r}+\alpha_{7} \text { NSS Round } d r+\alpha_{8} H i g h+\varepsilon \text { (1) } \\
& \text { Within - group } D D S_{h d r} \\
& =\alpha_{0}+\alpha_{1} F_{h d r}+\alpha_{2} H_{h d r}+\alpha_{3} \text { Lean }_{d r}+\alpha_{4} \sum_{j=1}^{3} T e m p_{j h d r}+\alpha_{5} \sum_{k=1}^{2} R F_{k h d r} \\
& +\alpha_{6} \text { Rural }_{h d r}+\alpha_{7} \text { NSS Round }_{d r}+\alpha_{8} \text { High }+\varepsilon(2) \\
& \operatorname{Pr}\left(\text { FoodGroup }_{\text {hdr }=1}=1\right) \\
& =F\left(\alpha_{0}+\alpha_{1} F_{h d}+\alpha_{2} H_{h d r}+\alpha_{3} \text { Lean }_{d r}+\alpha_{4} \sum_{j=1}^{3} T e m p_{j h d r}+\alpha_{5} \sum_{k=1}^{2} R F_{k h d r}\right. \\
& \left.+\alpha_{6} \text { Rural }_{h d r}+\alpha_{7} \text { NSS Round } d r+\alpha_{8} H i g h+\varepsilon\right)(3) \\
& \operatorname{Pr}\left(2 \text { Meals or } 3 \text { Meals }_{\text {hdri } i=1}=1\right) \\
& =F\left(\alpha_{0}+\alpha_{1} F_{h d r}+\alpha_{2} H_{h d r}+\beta_{1} I_{i h d r}+\alpha_{3} \text { Lean }_{d r}+\alpha_{4} \sum_{j=1}^{3} T e m p_{j h d r}\right. \\
& \left.+\alpha_{5} \sum_{k=1}^{2} R F_{k h d r}+\alpha_{6} \text { Rural }_{\text {hdr }}+\alpha_{7} \text { NSS Round } d r+\alpha_{8} H i g h+\varepsilon\right)(4)
\end{aligned}
$$

The first stage regression for each of these models is

$$
F_{h d r}=\phi_{0}+\phi_{1} N D V I_{h d r}+v(5)
$$

where $F_{h d r}=1$ if the household engaged in free collection, 0 otherwise and the NDVI $I_{h d r}$ varies by household and district-round based on the date of interview.

\footnotetext{
${ }^{8}$ Some of these variables could be endogenous themselves and this is addressed in the section on robustness checks.
} 
We further control for household characteristics $\left(H_{h d r}\right)$ to address selectivity bias, i.e., that are potential sources of omitted variable bias. We control for land ownership, which is a proxy for own production, occupation, monthly per capita expenditure (MPCE) as a proxy for income, household size. Occupation and education levels similarly proxy for socio-economic status. Social group and religion capture not only status but also food habits and beliefs, although we do not have specific information on what these food-related norms might be.

The model errors are clustered at the district level, given that the district is a relevant unit for shared unobservable characteristics, including administration, welfare programmes, demography and geography. For individual data on the number of meals per day, errors are clustered at the household level to take into account correlations within members of the household. We include a vector of individual characteristics, including education, age, square of age and gender $\left(I_{\text {indr }}\right){ }^{9}$

In general, for these models, fixed effects are included for districts that have significant CPRs, including forests, grasslands and water bodies, and therefore offer more opportunities for free collection. These settings might both be associated with higher rates of free collection but also independently greater dietary diversity in general, on account of the wide range of foods available overall even in markets. I use the Location Quotient (LQ) to identify these districts. This is computed as the ratio of share of value of food consumption sourced from free collection in district $d$ and the share of value of food consumption sourced from free collection nationwide. High free collection districts are those with an LQ greater than 1, the rest are deemd Low free collection districts. Given that the short time gap of one year between the two rounds of data that are pooled, the concern that these districts might change in response to free collection is minimal. Indeed, across the two rounds of data, the pattern suggests that the cluster of districts deemed High districts are somewhat stable (Figure 1, discussed in Section 4).

\footnotetext{
${ }^{9}$ In addition I implement a two-way cluster model, where errors are clustered both at the household and state. These results are available from the author.
} 
To avoid the problem of a first stage probit regression (the 'forbidden' regression), the first stage is implemented as a least sqaures and the two stages are estimated jointly. The system is exactly identified. The coefficient of on $F_{h d r}$ in each of the equations forms the basis for computing the impacts. Given that it is a binary variable, and where the dependent variable is in logarithm of dietary diversity scores, the interpretation is not trivial, especially when the coefficient is large (Giles, 2011). The accurate effect of free collection on the outcome, when the outcome is in log terms is, in this case,

$$
e^{\alpha_{1}}-1
$$

For within-food group dietary diversity scores we take logarithm by transforming the value, by adding 1 , to avoid 0 values, but also implement a version where I use actual scores, given the limited number of 0 values. For food group-wise models (Models 2 and 3), I limit interpretation to the direction and strength of the coefficients, to identify the food groups that drive the results for HDDS.

\section{Free collection of Foods in India: Estimates, patterns and trends}

Estimates based on the NSS survey data suggests that $5.8 \%$ of all Indian households relied on free collection of at least food item, over a one month recall period, in 2011-12 (Table 1). This number has declined dramatically in less than decade, from over $12 \%$ in 200405 (estimates not reported in this paper). In districts where free collection is higher than the national rate, the proportion of households that collects food is as high as $15 \%$. Across the country, among those who collect food, the average number of items is 1.31 , accounting for $4.5 \%$ of the total value of all food consumption. Both the number of items and share in value of consumption have remained stable over the two rounds, and indeed even relative to 200405 (not reported here) suggesting that the dependence on free collection of those who collect food has continued to be important. These averages naturally mask the extent to which people depend on free collection; as per the data for at least $10 \%$ of the households that collect food, it constitutes approximately $13 \%$ of the total value of food consumption. Some households, for example, depend overwhelmingly on free collection. As one would expect, some 
commodities are more commonly collected free than others, both in terms of the number of households who engage in free collection and the share in total consumption of these items that is sourced free. These include fish, Green Leafy Vegetables (GLVs), vegetables, fruits, vegetables and meats (Table 2).

Table 1: All India estimates of CPRs as sources of food

\begin{tabular}{lcc}
\hline Particulars & $\begin{array}{c}2009-10 \\
\text { Round 66 }\end{array}$ & $\begin{array}{c}2011-12 \\
\text { Round 68 }\end{array}$ \\
\hline $\begin{array}{l}\text { Percentage of households sourcing at leat one item } \\
\text { Average number of items exclusively from free collection }\end{array}$ & $\mathbf{6 . 5}$ & $\mathbf{5 . 8}$ \\
All households & 0.087 & 0.076 \\
Free-collection households & 1.33 & 1.31 \\
Average percentage of value of consumption from free collection & \\
All households & 0.29 & 0.267 \\
Free-collection households & 4.47 & 4.5 \\
\hline
\end{tabular}

Source: National Sample Survey, multiple rounds.

Table 2: Food group-wise free collection for pooled cross-section (2011-12 and 2009-10)

\begin{tabular}{lcccc}
\hline & \multicolumn{2}{c}{$\begin{array}{c}\text { Proportion of } \\
\text { households who } \\
\text { collect foods }\end{array}$} & $\begin{array}{c}\text { Share of free collection in } \\
\text { Fotal value of } \\
\text { consumption }\end{array}$ & \\
\cline { 2 - 5 } & $\begin{array}{c}\text { Among free } \\
\text { collectors }\end{array}$ & All & $\begin{array}{c}\text { Free collection } \\
\text { households }\end{array}$ & All \\
\hline Cereals & 1.36 & 0.08 & 0.60 & 0.04 \\
Cereal substitutes & 0.26 & 0.02 & 4.82 & 0.18 \\
Pulses, legumes, nuts & 0.99 & 0.06 & 0.43 & 0.03 \\
Sugar, salt, spices & 10.47 & 0.64 & 1.06 & 0.07 \\
Meats, offal, etc. & 5.52 & 0.34 & 8.15 & 0.51 \\
Vegetables & 21.50 & 1.31 & 9.07 & 0.57 \\
Fruits & 26.03 & 1.59 & 15.80 & 0.89 \\
Milk & 0.97 & 0.06 & 1.73 & 0.07 \\
Egg & 0.12 & 0.01 & 0.29 & 0.02 \\
Fish & 24.17 & 1.48 & 41.56 & 4.51 \\
Green Leafy Vegetables & 34.27 & 2.09 & 41.96 & 2.93 \\
Beverages & 0.40 & 0.02 & 0.37 & 0.02 \\
\hline Nite: Milk produts, edible
\end{tabular}

Note: Milk products, edible oils excluded, since they are processed forms.

The practice of free collection of food also has spatial and temporal dimensions. Figure 1 shows the districts where free collection is more intensive than the overall national average. Between 2009-10 and 2011-12, it is easy to see that there is not much change in the geographies that are important (Figure 1). The figure suggests that free collection is pervasive 
restricted not just to forested districts but common in arid, semi-arid and coastal districts as well (Figure 2).

Figures 3, 4 and 5 illustrate seasonal patterns based on location, where seasonality is captured based on the date of the interview. These are local polynomial curves that plot variables of interest by the day of the year in which they were interviewed (Day 1 to 365 maps the calendar year). Rural households are in general more likely to collect food free relative to urban households; they also exhibit more seasonal variation in accessing free food (Figure 3). An analogous comparison between High and Low free collection districts suggests that while the former, by construction, has a higher proportion of households who collect food free, those in these districts tend also to collect more number of items identified in the survey. Figure 5 maps the Household Dietary Diversity Score for all households in High and Low districts, which is higher in High districts relative to Low districts. The HDDS also shows substantial variation in both across the year and a very distinct seasonal slump in both, albeit more pronounced in the Low districts. The left panel plots the share of value of food consumption from free collection by monthly per capita expenditure (MPCE) in thousand rupees. Although free collection is often associated with the poor, the figure suggests a more complex relationship with a distinct "middle-income" bias. In the context of literature on the commons, this is consistent with the idea that access to commons is often appropriated by the non-poor (Chopra \& Dasgupta, 2008). 
Figure 1: Districts with high rates of free collection of food based on Location Quotients (2009-10 and 2011-12)
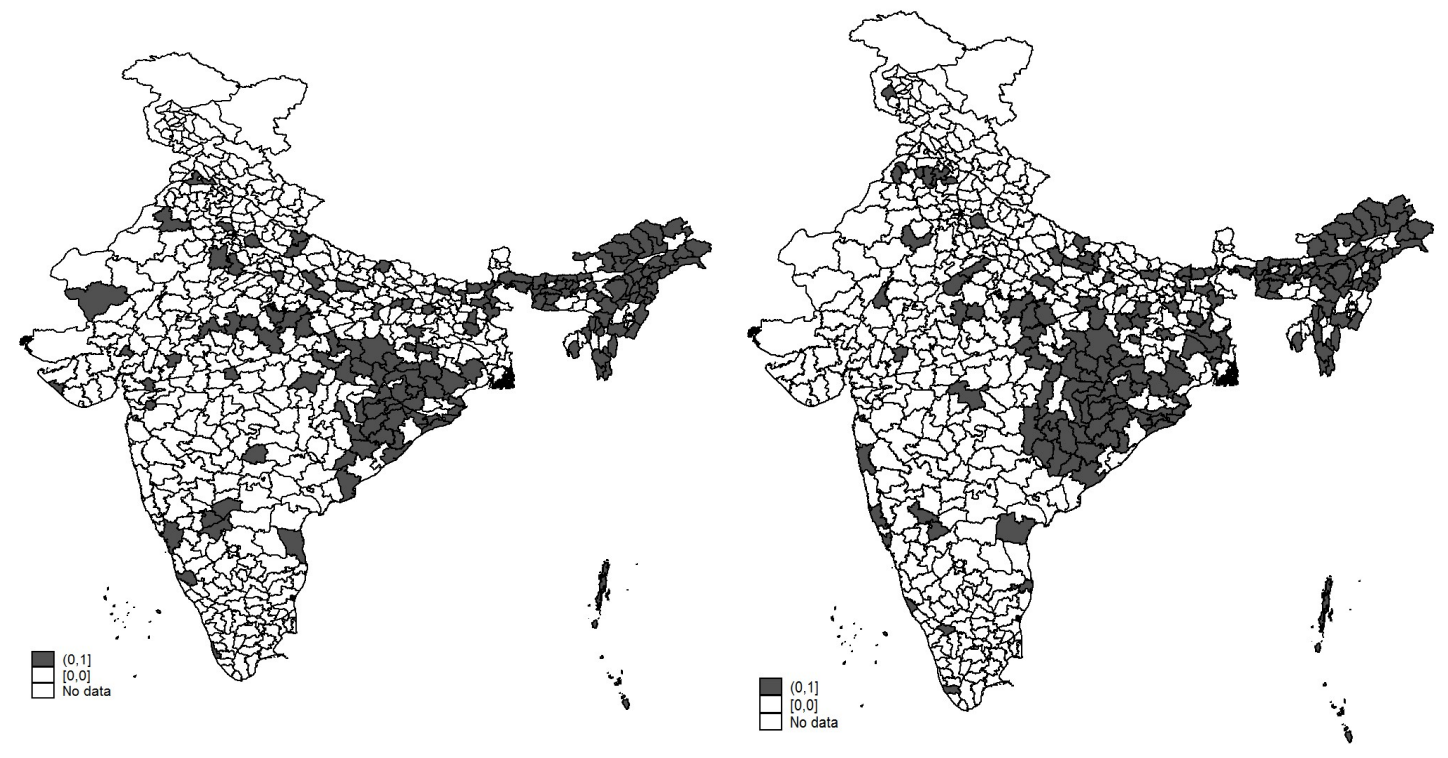

Figure 2: Distribution of districts based on proportion of households undertaking free collection of foods. (2009-10 and 2011-12)

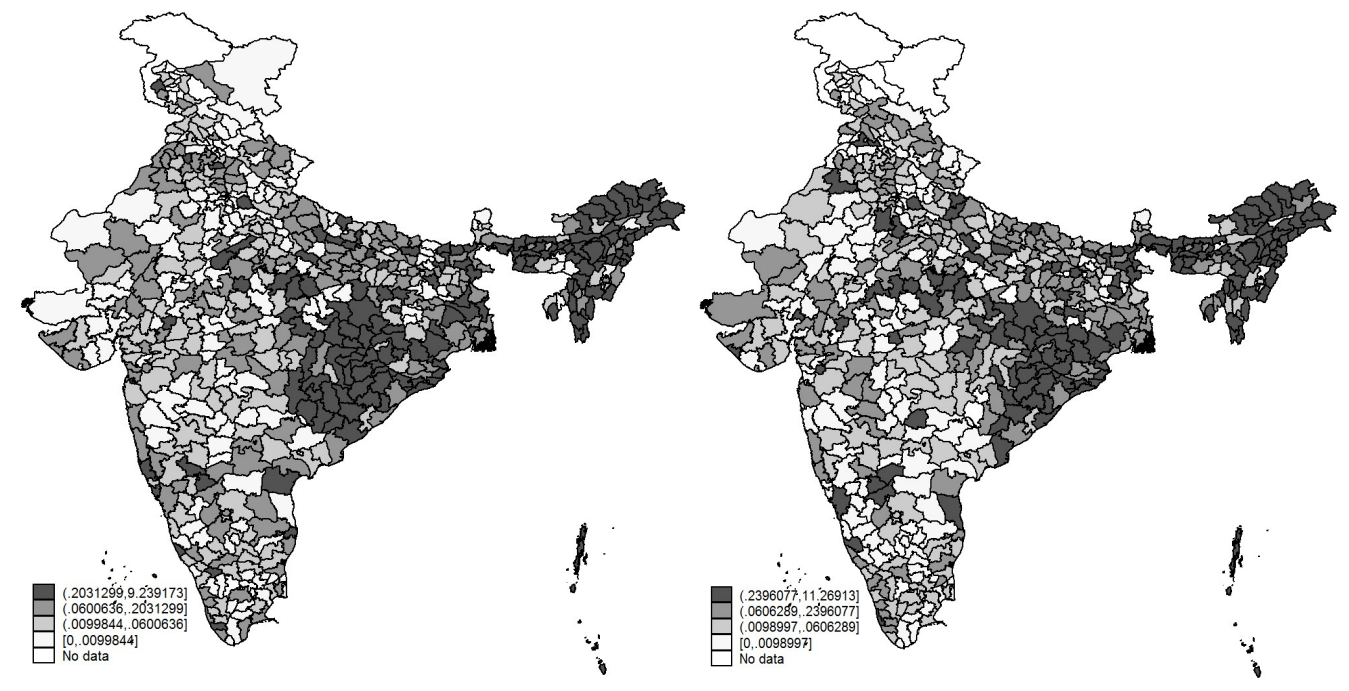


Figure 3: Rural versus Urban Free Collection

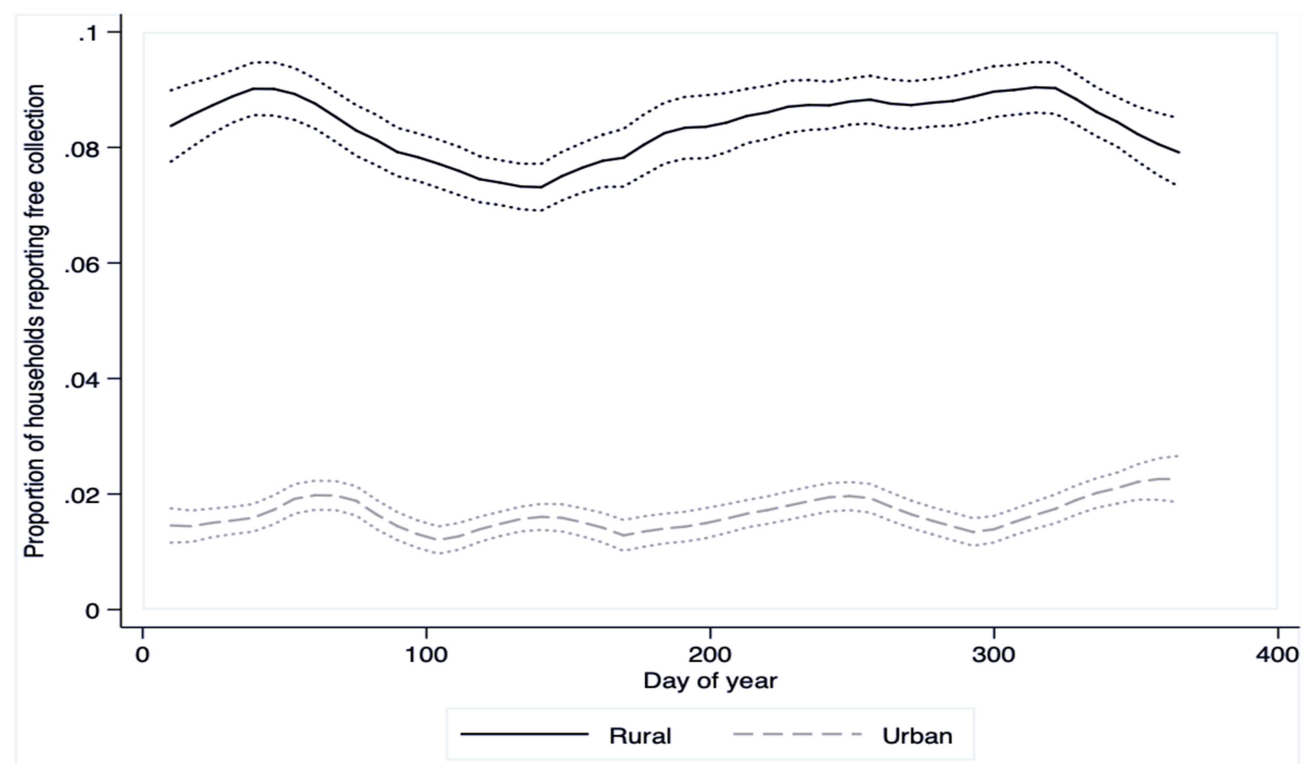


Figure 4 : Free food collection in High and Low districts over the year
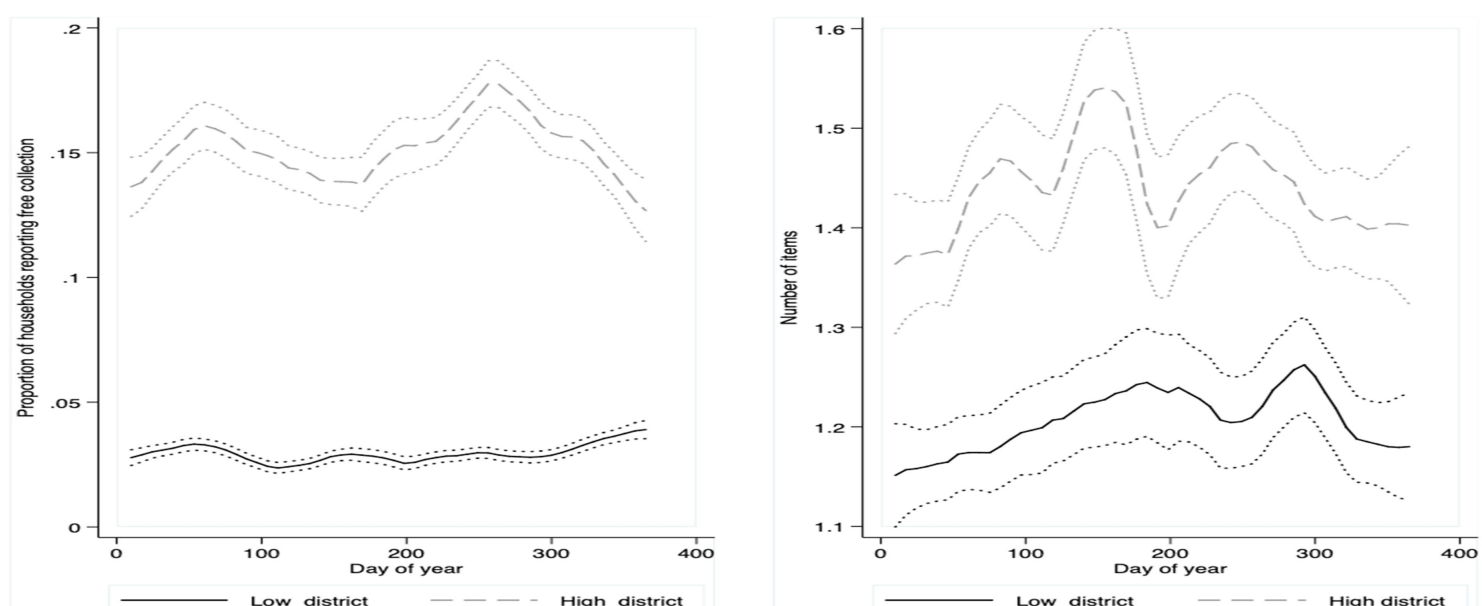

Figure 5: Household dietary diversity score and number of food groups collected
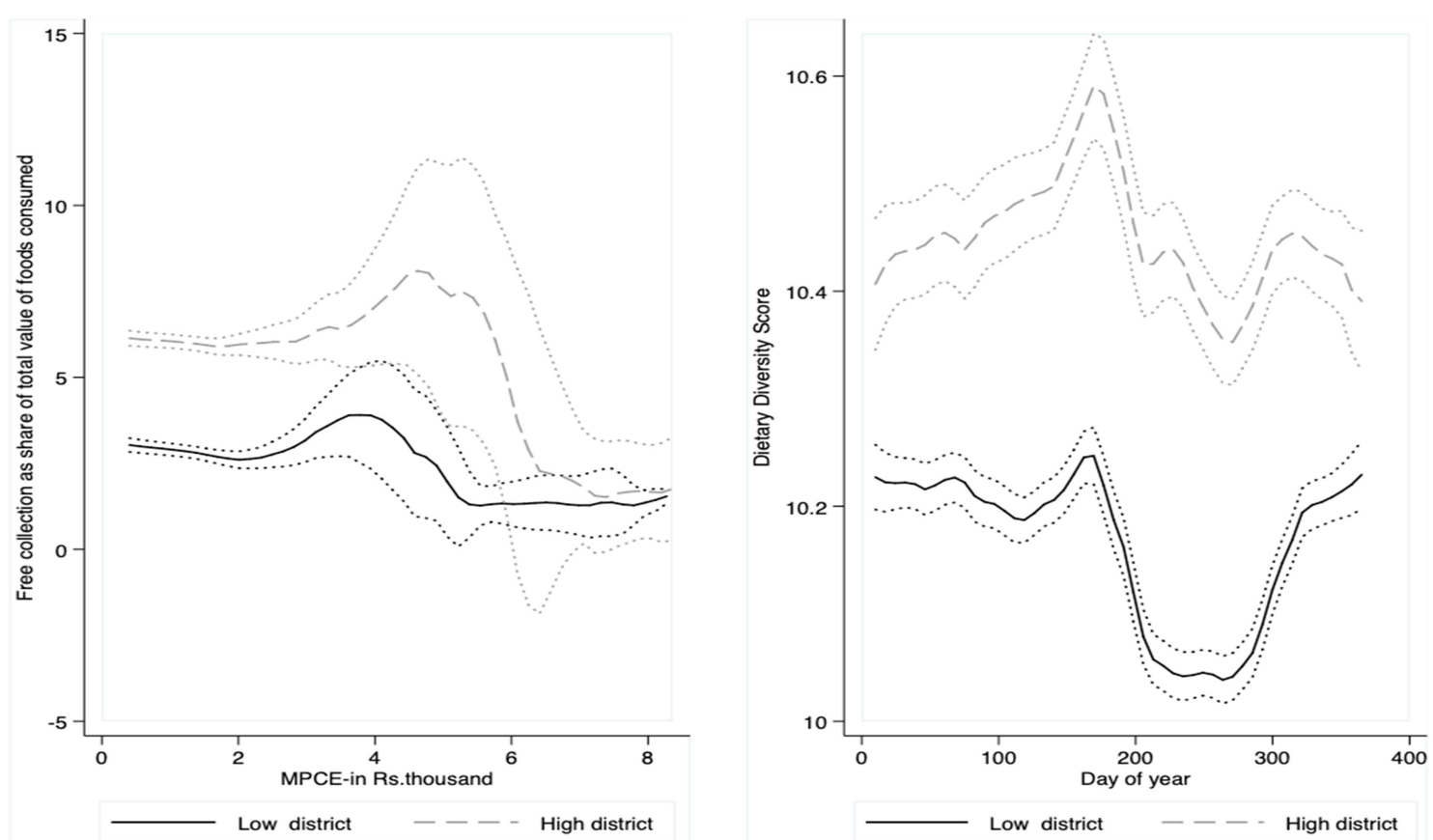


\section{Results and Discussion}

Table 3 presents the summary statistics of the variables included in the models. Households that collect food differ from those who do not with respect to a number of covariates, including occupation and social group and education, with the more disadvantaged more likely to collect food. Those with lower monthly per capita expenditure (MPCE) on average are more likely to draw on free sources of food, as are those with lower exclusive dependence on own production and higher exclusive dependence on the market, etc. Many of these are somewhat intuitive and along expected lines. When comparing samples based on location in High and Low collection districts or time of the survey (Lean versus non-Lean seasons) there are fewer significant differences, especially in time invariant characteristics,. In general, a higher fraction of households collect free food in the Lean season and in High collection districts (the latter, by construction). The summary statistics provide evidence that the timing of the survey indeed reflects significant time varying differences across sample households, but the households do not systematically differ based on when they were interviewed. In contrast, the households differ somewhat systematically based on whether they are located in High collection districts or not.

I estimate Models 1,2, 3 and 4, described in Section 3, noting that on account of the differences across methods, results presented here and those presented in the next section are not comparable with one another, since they identify the effects of free collection for different subpopulations. Table 4 summarizes the coefficients of the variable Free Collection, which, from the perspective of causal inference represents the treatment effects identified by the use of instruments. The corresponding endogeneity test and identification tests are in Appendix B (Table B.1, Supplementary Materials online). These suggest the presence of endogeneity and hence the relevance of an IV approach. It also provides statistical evidence that the model is not underidentified and the instrument is relevant and strong. The first stage results are

published in Appendix B, Table B.2 (Supplementary Materials online). The relationship of covariates of the first stage regression is along expected lines. Those in High free collection 
districts, those living in rural areas, those with larger households, and in households that experienced positive rainfall shocks are all more likely to engage in free collection. Households from marginalized communities are also more likey to rely on such collection. Casual workers are less likely to rely on free collection, since their dependence on the market might be higher and on own prodcution, lower. The lean season too is associated with a lower probability of free collection, when conditioned on NDVI. In alternate models, not presented here, it is positively related when weather and climatic factors are not included, as one would expect. There is a strong negative correlation between sourcing from markets and own production and free collection - which is indeed what one would expect if free collection substitutes for other sources of food. Education is negatively correlated with free collection; but conditioned on location and social group, the poor are marginally less likely to use free collection. The difference is not significant, but the direction is consistent with observations by others that access to commons and natural resources often exclude the poor (Chopra and Dasgupta, 2008).

Does free collection matter for dietary adequacy and quality? In terms of dietary adequacy, we do not find a statistically significant effect on the probability that an individual obtains at least two meals a day. However, free collection is associated with a higher probability of having three or more meals a day, suggesting that free collection does have the potential to expand the number of meals beyond the basic needs, but not necessarily in fulfilling a basic requirement of two meals a day. 
Table 3: Summary statistics: Pooled cross-section

\begin{tabular}{|c|c|c|c|c|c|c|c|}
\hline Variables & $\begin{array}{c}\text { No free collection } \\
\text { households }\end{array}$ & $\begin{array}{l}\text { Free collection } \\
\text { households }\end{array}$ & Not lean & Lean season & Low district & $\begin{array}{c}\text { High } \\
\text { District }\end{array}$ & All \\
\hline Hindu $(=1)$ & 0.76 & 0.68 & 0.76 & 0.76 & 0.78 & 0.69 & 0.76 \\
\hline Scheduled Castes $/$ Tribes $=1$ & 0.27 & 0.57 & 0.29 & 0.29 & 0.25 & 0.43 & 0.29 \\
\hline Dependency ratio & 30.15 & 33.80 & 30.23 & 30.70 & 30.25 & 30.74 & 30.36 \\
\hline Female-headed household & 0.11 & 0.11 & 0.11 & 0.12 & 0.12 & 0.10 & 0.11 \\
\hline Age of the head of the household & 46.49 & 45.28 & 46.39 & 46.49 & 46.59 & 45.80 & 46.42 \\
\hline Number of members completed primary education & 2.65 & 2.18 & 2.62 & 2.63 & 2.62 & 2.66 & 2.62 \\
\hline education & 0.78 & 0.32 & 0.76 & 0.74 & 0.78 & 0.66 & 0.76 \\
\hline Household size & 4.60 & 4.77 & 4.60 & 4.65 & 4.59 & 4.66 & 4.61 \\
\hline Most educated member has primary education $(=1)$ & 0.94 & 0.89 & 0.94 & 0.94 & 0.94 & 0.94 & 0.94 \\
\hline Owned any Land & 0.86 & 0.93 & 0.87 & 0.87 & 0.86 & 0.88 & 0.87 \\
\hline Total Land possessed (acres/ or hectares) & 6.09 & 5.79 & 6.18 & 5.81 & 5.79 & 7.19 & 6.08 \\
\hline Casual worker-household (=1) & 0.27 & 0.41 & 0.27 & 0.28 & 0.28 & 0.27 & 0.28 \\
\hline Monthly per capita expenditure (Rs. `000) & 1.73 & 1.14 & 1.72 & 1.65 & 1.75 & 1.52 & 1.70 \\
\hline Growing degree days & 5006.53 & 5035.49 & 5013.80 & 4993.14 & 4956.99 & 5178.85 & 5008.25 \\
\hline Days below threshold & 22.50 & 29.36 & 22.64 & 23.62 & 21.22 & 28.52 & 22.90 \\
\hline Days above threshold & 41.01 & 30.36 & 40.52 & 39.97 & 44.38 & 27.04 & 40.37 \\
\hline Negative deviation in rainfall & -1.04 & -1.15 & -0.96 & -1.27 & -1.03 & -1.10 & -1.04 \\
\hline Mean Normalized density of vegetation index (NDVI) & 5027.72 & 5647.77 & 4756.91 & 5851.62 & 4883.19 & 5669.82 & 5064.02 \\
\hline Positive deviation in rainfall & 1.13 & 1.10 & 1.32 & 0.60 & 1.13 & 1.12 & 1.13 \\
\hline Home production & 86.51 & 72.17 & 85.92 & 85.01 & 87.17 & 80.39 & 85.68 \\
\hline Market purchases & 11.57 & 18.26 & 11.80 & 12.35 & 11.02 & 15.21 & 11.94 \\
\hline Home production and market purchases & 0.85 & 2.53 & 0.90 & 1.05 & 0.68 & 1.89 & 0.94 \\
\hline Household food price index & 277.91 & 221.68 & 272.44 & 280.87 & 280.17 & 255.49 & 274.70 \\
\hline District food price index & 303.27 & 271.38 & 301.55 & 301.18 & 312.17 & 263.80 & 301.45 \\
\hline
\end{tabular}




\begin{tabular}{|c|c|c|c|c|c|c|c|}
\hline District share of food sourced from the market & 73.34 & 67.92 & 73.10 & 72.76 & 74.26 & 68.61 & 73.01 \\
\hline Rural (=1) & 0.57 & 0.88 & 0.58 & 0.60 & 0.56 & 0.67 & 0.59 \\
\hline Lean & 0.27 & 0.28 & & & 0.27 & 0.28 & 0.27 \\
\hline High free collection district (Location Quotient $>=1$ ) & 0.20 & 0.60 & 0.22 & 0.23 & - & - & 0.22 \\
\hline Observations & 202517 & & 202517 & & & & \\
\hline Outcome variables & $\begin{array}{c}\text { No free collection } \\
\text { households }\end{array}$ & $\begin{array}{c}\text { Free collection } \\
\text { households } \\
\end{array}$ & Not lean & Lean season & Low district & $\begin{array}{c}\text { High } \\
\text { District }\end{array}$ & All \\
\hline Free collection household & - & - & 0.06 & 0.06 & 0.03 & 0.15 & 0.06 \\
\hline Number of items from free collection & 0 & 1.36 & 0.07 & 0.08 & 0.03 & 0.22 & 0.08 \\
\hline Household dietary diversity score (log) & 2.40 & 2.39 & 2.40 & 2.42 & 2.39 & 2.42 & 2.40 \\
\hline Household dietary diversity score (past month) & 10.26 & 10.13 & 10.22 & 10.35 & 10.17 & 10.42 & 10.22 \\
\hline Cereal consumption $(1=$ Yes $)$ & 0.98 & 0.98 & 0.98 & 1.00 & 0.98 & 0.99 & 0.98 \\
\hline Roots and Tubers consumption ( $1=$ Yes $)$ & 0.94 & 0.94 & 0.94 & 0.94 & 0.94 & 0.95 & 0.94 \\
\hline Vegetables consumption ( $1=$ Yes $)$ & 0.98 & 0.98 & 0.98 & 1.00 & 0.98 & 0.98 & 0.98 \\
\hline Green leafy vegetables (1=Yes) & 0.77 & 0.66 & 0.73 & 0.84 & 0.73 & 0.77 & 0.74 \\
\hline Fruits consumption $(1=$ Yes $)$ & 0.82 & 0.84 & 0.83 & 0.75 & 0.84 & 0.78 & 0.83 \\
\hline Meat and eggs $(1=$ Yes $)$ & 0.62 & 0.60 & 0.61 & 0.69 & 0.59 & 0.71 & 0.61 \\
\hline Fish and seafood consumption ( $1=$ Yes $)$ & 0.38 & 0.38 & 0.36 & 0.61 & 0.31 & 0.60 & 0.38 \\
\hline Pulses/legumes/nuts $(1=$ Yes $)$ & 0.97 & 0.97 & 0.97 & 0.97 & 0.97 & 0.97 & 0.97 \\
\hline Milk (1=Yes) & 0.86 & 0.86 & 0.87 & 0.65 & 0.89 & 0.75 & 0.86 \\
\hline Oils (1=Yes) & 0.98 & 0.98 & 0.98 & 0.97 & 0.98 & 0.97 & 0.98 \\
\hline Sugar/honey (1=Yes) & 0.97 & 0.96 & 0.97 & 0.95 & 0.97 & 0.96 & 0.97 \\
\hline Miscellaneous ( $1=$ Yes $)$ & 0.99 & 0.99 & 0.99 & 0.98 & 1.00 & 0.99 & 0.99 \\
\hline Cereals diversity & 4.67 & 4.62 & 4.68 & 4.23 & 4.73 & 4.40 & 4.66 \\
\hline Vegetables & 7.64 & 7.21 & 7.57 & 6.86 & 7.60 & 7.28 & 7.53 \\
\hline Fruits & 2.04 & 1.98 & 2.05 & 1.58 & 2.08 & 1.81 & 2.03 \\
\hline Meat, poultry, offal F. Eggs & 1.14 & 1.12 & 1.13 & 1.30 & 1.08 & 1.34 & 1.14 \\
\hline Pulses/legumes/nuts & 5.06 & 5.05 & 5.13 & 3.86 & 5.33 & 4.08 & 5.06 \\
\hline
\end{tabular}




\begin{tabular}{|c|c|c|c|c|c|c|c|}
\hline Milk and milk products & 2.10 & 2.09 & 2.13 & 1.45 & 2.19 & 1.77 & 2.10 \\
\hline Oil/fats & 2.24 & 2.26 & 2.25 & 2.19 & 2.25 & 2.23 & 2.25 \\
\hline Sugar/honey & 1.38 & 1.34 & 1.37 & 1.31 & 1.38 & 1.30 & 1.37 \\
\hline Miscellaneous & 4.21 & 4.14 & 4.21 & 3.94 & 4.18 & 4.22 & 4.19 \\
\hline
\end{tabular}

Source: Based on NSS $66^{\text {th }}$ and $68^{\text {th }}$ rounds. Within-group diversity is not presented for GLV, Fish and roots/tubers since these are aggregated into one category. 
Table 4 : Second Stage coefficients from the Instrumental Variable Model

\begin{tabular}{|c|c|c|c|c|c|}
\hline \multirow{2}{*}{$\frac{\text { Dependent variable }}{\text { Two square meals }(=1)}$} & \multicolumn{2}{|c|}{ NDVI as instrument } & \multicolumn{2}{|c|}{ LEAN as instrument } & \multirow[t]{2}{*}{$\begin{array}{l}\text { Nature of } \\
\text { impacts }\end{array}$} \\
\hline & -0.0131 & $(0.02)$ & 0.0894 & $(0.06)$ & \\
\hline Three meals $(=1)$ & $1.7525 * * *$ & $(0.26)$ & $3.6906 * * *$ & $(1.14)$ & Positive impact \\
\hline Household dietary diversity score $(\log )$ & $1.6715^{* * *}$ & $(0.41)$ & $3.6524^{* *}$ & (1.76) & Positive impact \\
\hline $\begin{array}{l}\text { Household dietary diversity score (past } \\
\text { month) }\end{array}$ & $17.8144 * * *$ & $(4.37)$ & $37.7792 * *$ & $(18.25)$ & Positive impact \\
\hline \multicolumn{6}{|c|}{ Whether this foodgroup is consumed (excludes cereal consumption since too few households do not) } \\
\hline Cereal consumption $(1=\mathrm{Yes})$ & - & - & - & - & \\
\hline Roots and Tubers consumption ( $1=$ Yes) & -0.3385 & $(0.37)$ & 0.4546 & $(0.52)$ & No impact \\
\hline Vegetables consumption $(1=$ Yes $)$ & -0.0223 & $(0.03)$ & -0.0741 & $(0.08)$ & No impact \\
\hline Green leafy vegetables $(1=$ Yes $)$ & $1.5147^{*}$ & $(0.89)$ & $21.8609 * *$ & (10.57) & Positive impact \\
\hline Fruits consumption $(1=$ Yes $)$ & $-2.5377 * * *$ & $(0.70)$ & $-5.2002 *$ & $(2.71)$ & Negative impact \\
\hline Meat and eggs $(1=$ Yes $)$ & $7.7059^{* * *}$ & $(1.79)$ & $9.7503 * *$ & $(4.79)$ & Positive impact \\
\hline Fish and seafood consumption ( $1=$ Yes $)$ & $15.1166^{* * *}$ & $(3.25)$ & $15.1850 * *$ & $(7.41)$ & Positive impact \\
\hline Pulses/legumes/nuts (1=Yes) & $-0.2526^{* *}$ & $(0.11)$ & -0.3872 & $(0.36)$ & Mixed \\
\hline Milk $(1=$ Yes $)$ & $-2.8616 * * *$ & $(0.74)$ & $-3.4185^{* *}$ & (1.68) & Negative Impact \\
\hline Oils (1=Yes) & -0.2007 & $(0.13)$ & -0.3939 & $(0.32)$ & No impact \\
\hline Sugar/honey (1=Yes) & $-0.2843 *$ & $(0.16)$ & -0.2799 & $(0.30)$ & No impact \\
\hline Miscellaneous $(1=$ Yes $)$ & -0.0251 & $(0.06)$ & 0.2822 & $(0.21)$ & No impact \\
\hline \multicolumn{6}{|c|}{ Within food group diversity (excludes three groups that have only one item) } \\
\hline Cereals diversity & $-2.7411 * *$ & $(1.12)$ & -1.5917 & $(1.30)$ & Mixed \\
\hline Vegetables & $-2.8608 * * *$ & $(0.93)$ & $7.4586^{* *}$ & $(3.65)$ & Mixed \\
\hline Fruits & $-5.5399 * * *$ & $(1.42)$ & $-5.2031 *$ & $(3.00)$ & Negative impact \\
\hline Meat, poultry, offal F. Eggs & $8.5221 * * *$ & $(2.03)$ & $9.6742 * *$ & $(4.78)$ & Positive impact \\
\hline Pulses/legumes/nuts & $-7.9052 * * *$ & $(2.00)$ & $-9.9872 * *$ & $(5.08)$ & Negative impact \\
\hline Milk and milk products & $-4.4214 * * *$ & $(1.10)$ & $-4.9892 * *$ & $(2.46)$ & Negative impact \\
\hline Oil/fats & $1.0533 * *$ & $(0.50)$ & -0.9569 & $(0.74)$ & Mixed \\
\hline Sugar/honey & $-1.7412 * *$ & $(0.71)$ & 0.5207 & $(0.85)$ & Mixed \\
\hline Miscellaneous & 1.3552 & $(0.87)$ & $4.7648^{*}$ & $(2.45)$ & No impact \\
\hline
\end{tabular}


Table 5: Robustness checks for specification of the IV model

\begin{tabular}{|c|c|c|c|c|c|c|c|c|c|c|}
\hline Variables & (1) & (2) & (3) & (4) & (5) & (6) & (7) & (8) & (9) & (10) \\
\hline Effect & 0.77 & 1.48 & 0.98 & 0.98 & 0.95 & 0.07 & 1.88 & 2.90 & 3.72 & 3.50 \\
\hline \multirow{2}{*}{$\begin{array}{l}\text { Free collection household }(=1) \text { Coefficinet } \\
\text { p-value }\end{array}$} & $0.5732 * *$ & $0.9088 * * *$ & $0.6839^{* * *}$ & $0.6817 * * *$ & $0.6698 * * *$ & 0.0683 & $1.0585^{* * *}$ & $1.3612 * * *$ & $1.5519^{* * *}$ & $1.5030 * * *$ \\
\hline & $(0.13)$ & $(0.18)$ & $(0.16)$ & $(0.16)$ & $(0.16)$ & $(0.26)$ & $(0.29)$ & $(0.34)$ & $(0.41)$ & $(0.41)$ \\
\hline 1. Household characteristics & Yes & Yes & Yes & Yes & Yes & Yes & Yes & Yes & Yes & Yes \\
\hline 2. Household food price index & Yes & Yes & Yes & Yes & Yes & Yes & Yes & Yes & Yes & Yes \\
\hline \multirow{2}{*}{$\begin{array}{l}\text { 3. District food price index } \\
\text { 4. Shares sourced from market, own } \\
\text { production }\end{array}$} & No & No & Yes & Yes & Yes & Yes & Yes & Yes & Yes & Yes \\
\hline & No & Yes & Yes & Yes & Yes & Yes & Yes & Yes & Yes & Yes \\
\hline $\begin{array}{l}\text { 5. District mean share sourced from } \\
\text { market }\end{array}$ & No & No & No & No & No & No & Yes & Yes & Yes & Yes \\
\hline 6. Sector & No & No & No & Yes & Yes & Yes & Yes & Yes & Yes & Yes \\
\hline 7. Round & No & No & No & No & Yes & Yes & Yes & Yes & Yes & Yes \\
\hline 8. State fixed effects & No & No & No & No & No & Yes & No & No & No & No \\
\hline 9. High collection district & No & No & No & No & No & No & Yes & Yes & Yes & Yes \\
\hline 10. Sampling weights & No & No & No & No & No & No & Yes & No & No & No \\
\hline \multirow{2}{*}{$\begin{array}{l}\text { 11. Lean season } \\
\text { 12. Extended Lean season (July to } \\
\text { November) }\end{array}$} & Yes & Yes & Yes & Yes & Yes & Yes & Yes & No & No & No \\
\hline & No & No & No & No & No & No & No & Yes & No & No \\
\hline \multirow{2}{*}{$\begin{array}{l}\text { 13. Extended Lean season (May to Nov) } \\
\text { 14. Extended Lean season (May to } \\
\text { October) }\end{array}$} & No & No & No & No & No & No & No & No & Yes & No \\
\hline & No & No & No & No & No & No & No & No & No & Yes \\
\hline
\end{tabular}

In all models, standard errors are clustered at the district level, the level at which the instrument is measured. * $10 \%$ level ** 5\% level and *** $1 \%$ level of significance 
The impacts on HDDS differ widely across models (Table 5). These estimates are comparable within the class of IV models that use NDVI as instrument. In the preferred model, the HDDS of free collection households is 4.3 times more than what it would have been without free collection. The preferred model appears to generate among the highest estimates among all the alternatives implemented. On account of the potential threat of endogeneity of several variables, I test the sensitivity of the estimates to specification (Table 5). This includes alternate definitions of the lean seasons (mentioned in Table 5), incorporation of state level fixed effects, weighting regressions. The key checks for sensitivity to specification, however pertain to the inclusion of shares that the household sources from own production and markets, and household and district food price index. As expected, the estimates vary substantially (from around a 77\% increase to over 4-fold increase). Estimates when these additional market related variables seems to strengthen the relationship between free collection and dietary diversity. The estimates from this range of models however vary only in degree and not in direction. The results require cautious interprestation since the overall IV effect represents treatment effects over a continuous instrument with a binary treatment. As such, it is not as straightforward as a LATE interpretation for a Wald estimate. The treatment effect is defined for compliers at different pairs of values of the instrument and might be driven by large treatment effects for some individuals (Cornelissen et al., 2016).

Table 4 suggests that free collection increases the probability of consuming gren leafy vegetables and fish by about $10-11$ percentage points, with about 2.6 percentage point increases in meat consumption. In this paper I restrict the interpretation on within group dietary diversity to direction rather than to degree, because as mentioned earlier, the survey does not capture the within group diversity adequately and interpretation can therefore be misleading. The impacts on dietary diversity are driven by specific food groups, name meat, eggs, fish, green leafy vegetables (Table 4). For commodities, other than these, free collection of food does not increase the likelihood of including /consuming that food group. One interpretation could be that these are not the items that the household can source from the 
commons and is hence intuitive in that sense. It could however also imply that the free collection of these products, that represent an implicit transfer, has not crowded in or enabled the consumption of new food groups. On the contrary, we find that free collection reduced the likelihood that milk is consumed. Field studies from India suggest that milk as a source of protein is substituted for by pulses and animal proteins when milk is unavailable or too expensive (Pandey, et al, 2019). This likely reflects such a phenomenon.

\section{Robustness Checks}

I conduct a number of checks to assess if the results are robust. The first is akin to a falsifiction test. In the Indian context, since free collection of foods is likely restricted to unprocessed foods, as evident in Table 2, processed items such as edible oils, milk products or certain beverages and packaged foods would not show an impact since the opportunities for free collection of these are minimal. This is indeed the case. ${ }^{10}$

The set of controls representing shares sourced by different means are potentially endogenous. A household can decide where to source food, market, own stocks or to collect foods free and these are often simultaneous decisions. To account for this, I endogenize the shares from different sources, using the temperature, rainfall and NDVI as instruments for market shares. The results, available in Supplementary Materials (Appendix C) suggests that the relationship between free collection and household dietary diversity is robust and close to the estimates from the preferred model.

Using NDVI as an instrument identifies impacts for the subgroup of households who collect food on account of an exogenous change in the NDVI. There is however some concern that the NDVI does not credibly pick up the presence of water bodies, which becomes and important source of free food when households are vulnerable to shortages from other sources. I therefore test the sensitivity of the impacts to an alternate IV, a binary variable that takes the value 1 for the Lean season and 0 otherwise. This is therefore a Wald estimate of

\footnotetext{
10 These results are available from the author.
} 
treatment effects. The use of this IV identifies impacts for a different subsample, of those who on account of lean/non-lean season are driven to (not) source food free (Table 2). For this reason, it is not strictly comparable with the preferred model. That said, as with the specification checks, the direction of the relationship remains, with only the strength changing.

To examine the sensitivity to methods, and as an alternative to the IV approach, we use propensity score matching and triple and quadruple difference techniques. In the PSM approach, propensity score is estimated on a range of covariates, including the instrument (Ichimura and Taber, 2001), I present results for ATT based on matching of propensity scores with five nearest neighbours on the common support, with calipers of 0.05 . Twelve treated observations are dropped that do not have a match and the remaining observations, including 160,486 comparison and 10398 treated units are used to compute treatment effects. The standard errors are bootstrapped to account for the estimation of the propensity score and the standardized bias reduction consequent to matching are shown in Appendix D. The PSM estimates of Average Treatment Effects on the Treated (ATET) with Abadie-Imbens standard errors (Abadie \& Imbens, 2006) suggest an impact of 0.27 increase in HDDS (which ranges from 1 to 12), much lower that those implied by other methods.

Apart from the IV approach and propensity score matching, the paper also implements a triple and quadruple difference model. This alternate approach helps in uncovering the differential associations based on location and season (Appendix E). With a set of interactive controls, we find that on average, those households who collect food have an HDDS of 0.07 and 0.13 higher than those who don't. This is the coefficient associated with the binary variable for free collection. The coefficients asssociated with the interaction terms involving the variable Free collection are not statistically significant. These estimates are even lowre than the matching estimates, but still strongly positive statistically.

Table 6 consolidates the results of all the models that assess the association of HDDS and free collection. The estimates are not strictly comparable across methods, since they 
identify impacts for different sub-populations. In general, the IV estimates tend to be larger than that the ATT and ATE estimated from PSM models or from a simple Triple/Quadruple Differences Model. The wide range of estimates, especially between the PSM approach and TD/QD approaches versus the IV is unsurprising. While the former identifies the impact averaged over the treated, i.e. the group that collects free food (including those who rely on free food routinely), the IV identifies it for a sub-population that uses free collection when supply of free foods expands exogenously, at different levels of NDVI. 
Table 6: Summary of results from different models

\begin{tabular}{cccl}
\hline Effect & Dependent variable & $\begin{array}{c}\text { Coefficient on } \\
\text { Free collection }\end{array}$ & Method \\
\hline $\mathbf{0 . 2 7}$ & HDDS & 0.27 & PSM with psmatch2, robust standard errors \\
$\mathbf{0 . 2 7}$ & HDDS & 0.27 & PSM with Abadie-Imbens Standard Errors \\
$\mathbf{4 . 3 2}$ & Log (HDDS) & 1.67 & IV Preferred specification \\
$\mathbf{0 . 7 7}$ & $\log$ (HDDS) & 0.57 & Robustness Check 1 \\
$\mathbf{1 . 4 8}$ & Log (HDDS) & 0.91 & Robustness Check 2 \\
$\mathbf{0 . 9 8}$ & Log (HDDS) & 0.68 & Robustness Check 3 \\
$\mathbf{0 . 9 8}$ & Log (HDDS) & 0.68 & Robustness Check 4 \\
$\mathbf{0 . 9 5}$ & Log (HDDS) & 0.67 & Robustness Check 5 \\
$\mathbf{-}$ & Log (HDDS) & 0.07 & Robustness Check 6 (Not significant) \\
$\mathbf{1 . 8 8}$ & Log (HDDS) & 1.06 & Robustness Check 7 \\
$\mathbf{2 . 9 0}$ & Log (HDDS) & 1.36 & Robustness Check 8 \\
$\mathbf{3 . 7 2}$ & Log (HDDS) & 1.55 & Robustness Check 9 \\
$\mathbf{3 . 5 0}$ & Log (HDDS) & 1.50 & Robustness Check 10 \\
$\mathbf{4 . 6 3}$ & Log (HDDS) & 1.73 & Endogenizing market shares \\
$\mathbf{0 . 0 7}$ & HDDS & 0.07 & Triple Difference \\
$\mathbf{0 . 1 3}$ & HDDS & 0.13 & Quadruple difference \\
\hline For the models with log dependent variables, the effect is the exponential of the coeffieicnt -1. For triple and \\
quadruple differences, only the coefficient is presented, since the interaction terms are not associated with \\
significant coefficients.
\end{tabular}




\section{Summary and Concluding Remarks}

This paper sought to ascertain the association between free collection of foods and dietary adequacy and diversity of households that engage in such collection. Despite the empirical challenges, the goal was to uncover plausibly causal relationships. The evidence suggests that while free collection does not contribute to ensuring two meals a day, it does enable an increase in the number of meals beyond two. On the other hand, there is consistent evidence on household level dietary diversity measured by a 12 group - Household Dietary Diversity Score (HDDS). A number of robustness checks imply wide variation in estimates (ranging form a $77 \%$ increase to a four-fold increase) but reassuringly all these different specifications and approaches emphatically support the hypothesis that access to free collection of foods augments household dietary diversity. These effects are confined to meats, fish, green leafy vegetables and vegetables more broadly, a notion consistent with existing micro-level field studies in India and elsewhere. Alternate approaches such as propensity score matching suggest more muted impacts of an increase in 0.27 in HDDS among the treated. The large effects from IV require cautious interpretation since it is a (Cornellilssan, et al., 201)

Together, these provide persuasive evidence for the role of free collection in the food security of individuals in India, making a strong case for mainstreaming discussions of sources of free foods such as common pool resources in food policy. Recent prescriptions on India's food systems focus on production, distribution and behavioural change (Pingali, et al., 2019; pages 277-311). This focus, important as it is, crowds out discussions on the role of CPRs and more generally free collection in improving dietary quality, an important lacuna in the current architecture of state-supported food distribution. The urgency of including free collection as an intrinsic part of policies that influence food enviroments is borne out by surveys of CPRs in India., which have reduced in area as well as in quality via degradation (Jodha, 1989; 1990). Among other things, a disproportionatee share of the burden of finds 
such food falls on women, who travel farther and for longer in search of these foods (Jodha, 1990; 1989). These concerns are not unique to India and in the larger context of food price inflation, underdeveloped markets and climate change issues, sources of free collection of foods need more careful attention and stewardship.

\section{References}

Abadie A. and Imbens, G. (2006), "Large sample properties of matching estimators for average treatment effects", Econometrica 74(1), 235-267.

Ahmed, S; Herforth, A. "Missing Wild and Cultivated Environments in Food Environment Measures" https://anh-academy.org/academy-news-events/blog/2017/08/30/missing-wildand-cultivated-environments-food-environment. Accessed September 30, 2018.

Ahmed, S.; Peters, C.M.; Chunlin, L.; Meyer, R.; Unachukwu, U.; Litt, A.; Kennelly, E.; Stepp, J.R. 2013. Biodiversity and Phytochemical Quality in Indigenous and State-Supported Tea Management Systems of Yunnan, China. Conservation Letters. 5 (6): 28-36

Beck, T. (1994) Common property resource access by poor and class conflict in West Bengal. Economic and Political Weekly 29, 187-197.

Belton, B., Thilsted, S.H., (2014) Fisheries in transition: Food and nutrition security implications for the global South, Global Food Security, 3(1):,59-66,

\section{https://doi.org/10.1016/j.gfs.2013.10.001}

Béné, C, and S.Heck (2005). "Fish and food security in Africa." NAGA, World Fish Center Quarterly 28, no. 3-4 (2005): 8-13.

Bharucha, Z., \& Pretty, J. (2010). The roles and values of wild foods in agricultural systems. Philosophical Transactions of the Royal Society B: Biological Sciences, 365(1554), 2913-2926. 
Bromley, D. W. (1992). The commons, property, and common-property regimes. Making the commons work.

Byker Shanks, C.; Smith, T.; Ahmed, S.; Hunts, H. 2015. Assessing Foods Offered in the Food Distribution Program on Indian Reservations (FDPIR) Using Healthy Eating Index2010. Public Health Nutrition doi:10.1017/S1368980015002359

Chopra, K., Dasgupta, P.(2008). "Nature of household dependence on common pool resources: An empirical study." Economic and Political Weekly 43: 58-66.

Cornelissen, T., Dustmann, C., Raute, A., \& Schönberg, U. (2016). From LATE to MTE: Alternative methods for the evaluation of policy interventions. Labour Economics, 41, 47-60. Davies, G. Frausin, G. \& Parry, L. (2017) Are There Food Deserts in Rainforest Cities? Annals of the American Association of Geographers, 107:4, 794811, DOI: $10.1080 / 24694452.2016 .1271307$

Deb,D., Kuruganti,K., Rao, V.R., Yesudas, S. (2014) Forests as Food Producing Habitats: An Exploratory study of Uncultivated Foods and Food \& Nutrition Security of Adivasis in Odisha, Living Farms.

FAO (2017) Making a Difference in Food Security and Nutrition, Committee on World Food Security, CFS2017/44/Report, October 2017. http://www.fao.org/3/a-mv030e.pdf

FAO and FANTA (2007) Guidelines for Measuring Household and Individual Dietary Diversity Food and Agriculture Organization of the United Nations (FAO) the Food and Nutrition Technical Assistance (FANTA) Project, Rome, Italy (2007)

Giles, D. E. (1982). The interpretation of dummy variables in semilogarithmic equations: Unbiased estimation. Economics Letters, 10, 77-79.

Godfray, H. C. J., Beddington, J. R., Crute, I. R., Haddad, L., Lawrence, D., Muir, J. F., Pretty, J, Robinson, S. Thomas, S.M \& Toulmin, C. (2010). Food security: the challenge of feeding 9 billion people. science, 327(5967), 812-818. 
Golden, C.D., Fernald, L.C.H., Brashares, J.S., Rasolofoniaina, B.J.R. \& Kremen, C. 2011. Benefits of wildlife consumption to child nutrition in a biodiversity hotspot. Proceedings of the National Academy of Sciences of the United States of America, 108(49): 19653- 19656. DOI:10.1073/pnas.1112586108.

Harou, A. P., Liu, Y., Barrett, C. B., \& You, L. (2017). Variable returns to fertiliser use and the geography of poverty: Experimental and simulation evidence from Malawi. Journal of African Economies, 26(3), 342-371.

Herforth, A.; Ahmed, S. 2015. The Food Environment, Its Effects on Dietary Consumption, and Potential for Measurement Within Agriculture-Nutrition Interventions. Food Security 7(3): 505-520

Hopping, B. N., Erber, E., Mead, E., Sheehy, T., Roache, C., \& Sharma, S. (2010). Socioeconomic indicators and frequency of traditional food, junk food, and fruit and vegetable consumption amongst Inuit adults in the Canadian Arctic. Journal of human nutrition and dietetics, 23, 51-58.

Ichimura, H, and Taber, C.. (2001) Propensity-score matching with instrumental variables. American Economic Review 91( 2): 119-124.

Ickowitz A, Rowland D, Powell B, Salim MA, Sunderland T (2016) Forests, Trees, and Micronutrient-Rich Food Consumption in Indonesia. PLOS ONE 11(5): e0154139.https://doi.org/10.1371/journal.pone.0154139

Ickowitz,A., Bronwen Powell, Mohammad A. Salim, Terry C.H. Sunderland (2014) Dietary quality and tree cover in Africa, Global Environmental Change, Volume 24, 2014,Pages 287294, https://doi.org/10.1016/j.gloenvcha.2013.12.001.

Iyengar, S. (1989) "Common property land resources in Gujarat: Some findings about their size, status and use." Economic and Political Weekly 24:A67-A77.

Iyengar, S., N.Shukla. (2002) "Common Property Land Resources in India: Some Issues in Regeneration and Management." Institutionalizing Common Pool Resources 301. 
Jodha, N. S (1989). Depletion of Common Property Resources in India: Micro-Level

Evidence. Population and Development Review, 15, 261-283. doi:10.2307/2807930

Jodha, N. S. (1986) "Common property resources and rural poor in dry regions of India." Economic and Political Weekly, 21: 1169-1181.

Jodha, N. S. (1990). Rural common property resources: contributions and crisis. Economic and Political Weekly, 25: A65-A78.

Johnson, K.B., Jacob A, Brown, M (2013) Forest cover associated with improved child health and nutrition: evidence from the Malawi Demographic and Health Survey and satellite data Global Health: Science and Practice , 1 (2) 237-248; doi: 10.9745/GHSP-D-13-00055

Lentz, E., Narayanan, S., De, A (2019) “Last and least: Findings on intrahousehold nutrition from participatory research in South Asia." Social Science and Medicine. 232: 316-323. https://doi.org/10.1016/j.socscimed.2019.05.024

Lobell, D. B., Sibley, A., \& Ortiz-Monasterio, J. I. (2012). Extreme heat effects on wheat senescence in India. Nature Climate Change, 2(3), 186-189.

Luckett BG, DeClerck FAJ, Fanzo J, Mundorf AR, Rose D.(2015) Application of the Nutritional Functional Diversity Indicator to Assess Food Systems Contribution to Dietary Diversity and Sustainable Diets of Malawian Households. Public Health Nutrition. 18: 24792487. doi: 10.1017/S136898001500169X. pmid:26027595

Msuya, J.M., Mamiro, P. \& Weinberger, K. (2009). Iron, zinc and $\beta$-carotene nutrient potential of non-cultivated indigenous vegetables in Tanzania. Acta Horticulturae (ISHS), 806: $217-222$.

Narayanan, S., Das, U., Liu, Y., \& Barrett, C. B. (2017). The "discouraged worker effect" in public works programs: Evidence from the MGNREGA in India. World Development, 100, 31-44. https://doi.org/10.1016/j.worlddev.2017.07.024 
NSSO (2013) Key Indicators of Household Consumer Expernditure, $68^{\text {th }}$ Round, NSS KI(68/1.0), National Sample Survey Organisation, 2013.

Pandey, V. L., Dev, S. M., \& Mishra, R. (2019). Pulses in eastern India: production barriers and consumption coping strategies. Food Security, 1-14.

Pearce, T., Smit, B., Duerden, F., Ford, J. D., Goose, A., \& Kataoyak, F. (2010). Inuit vulnerability and adaptive capacity to climate change in Ulukhaktok, Northwest Territories, Canada. Polar Record, 46(2), 157-177.

Pimentel, D., McNair, M., Buck, L., Pimentel, M., \& Kamil, J. (1997). The value of forests to world food security. Human ecology, 25(1), 91-120.

Pingali, P., Aiyar, A., Abraham, M., \& Rahman, A. (2019). Transforming food systems for a rising India. Springer. https://doi.org/10.1007/978-3-030-14409-8_1

Powell, B, S Haraksingh Thilsted, A Ickowizt, C Termote, T Sunderland and A Herforth. (2015). Improving Diets with Wild and Cultivated Biodiversity from Across the Landscape. Food Security 7(3): 535-554. https://doi.org/10.1007/s12571-015-0466-5

Powell, B., Maundu, P., Kuhnlein, H.V. \& Johns, T. (2013) Wild foods from farm and forest in the East Usambara Mountains, Tanzania. Ecology of Food and Nutrition 52(6), 451-478.

Powell, B., J. Hall, T. Johns (2011) Forest cover, use and dietary intake in the East Usambara Mountains, Tanzania International Forestry Review, 13.(3): 305317. https://doi.org/10.1505/146554811798293944

Rowland, D., Ickowitz, A. M. Y., Powell, B., Nasi, R., \& Sunderland, T. (2017). Forest foods and healthy diets: quantifying the contributions. Environmental Conservation, 44(2), 102114.

Sarangi,D., Biswal,B. and Patra, P. (2016) Forests: A Food Producing Habitat in A Multipronged Approach to Nutrition. CBGA Budget TRACK Volume 11, February 2016 
http://www.cbgaindia.org/wp-content/uploads/2016/03/Budget-Track-on-Nutrition-

Compressed.pdf

Termote, C., Meyi, M. B., Djailo, B. D. A., Huybregts, L., Lachat, C., Kolsteren, P., \& Van

Damme, P. (2012). A biodiverse rich environment does not contribute to a better diet: a case study from DR Congo. PloS One, 7(1), e30533.

Turner, C; Kalamatianou, S; Drewnowski, A; Kulkarni, B; Kinra, S; Kadiyala, S (2019) Food Environment Research in Low- and Middle-Income Coun- tries: A Systematic Scoping Review. Advances in nutrition (Bethesda, Md.). ISSN 2161-8313 doi:https://doi.org/10.1093/advances/nmz031

Turner, C.,Aggarwal, A, Walls, H., Herforth, A., Drewnowski,A., Coates,J., Kalamatianou, S., and Kadiyala.S (2018) "Concepts and critical perspectives for food environment research: A global framework with implications for action in low-and middle-income countries." Global Food Security 18: 93-101.

Vinceti, B., Ickowitz, A., Powell, B., Kehlenbeck, K., Termote, C., Cogill, B., \& Hunter, D. (2013). The contributions of forest foods to sustainable diets. Unasylva, 64(241), 54-64.

Vira,B. Wildburger, C. \& Mansourian S. (eds.), 2015. Forests, Trees and Landscapes for Food Security and Nutrition. A Global Assessment Report. IUFRO World Series Volume 33.Vienna. $172 \mathrm{p}$. 


\section{Online Supplementary Materials}

Appendix A: Construction of temperature and rainfall variables

\begin{tabular}{|c|c|c|c|}
\hline NDVI & $\begin{array}{l}2009-10 \\
2011-12\end{array}$ & $\begin{array}{l}\text { USGS-NASA (U.S. Geological } \\
\text { Survey). } \\
\text { https://lpdaac.usgs.gov/products/mo } \\
\text { dis products table/mod13a2 }\end{array}$ & $\begin{array}{l}\text { Vegetation Indices constructed every } 16 \text { days at 1-kilometer spatial resolution. } \\
\text { These are used as available by averaging the NDVI over two readings prior to } \\
\text { the date of the survey. }\end{array}$ \\
\hline Growing Degree Days & $\begin{array}{l}2009-10 \\
2011-12\end{array}$ & NASA & $\begin{array}{l}\text { GDD is the sum of excess of the mean average temperature over the base } \\
\text { temperature specified for the crop over its growing period for the particular } \\
\text { district } \\
\text { 1. } \mathrm{DD}=(\text { Tmax-Tmin }) / 2-\text { Tbase } \\
\text { 2. Cumulate the } \mathrm{DD} \text { for the dates denoting the growth period. } \\
G D D_{b \text { se opt }}=\sum_{t=1}^{N} D D_{t} \quad D D=\left\{\begin{array}{cc}0 & \text { if } T_{t}<T_{\text {base }} \\
T-T_{\text {base }} & \text { if } T_{\text {base }} \leq T_{t} \leq T_{o p t} \\
T_{o p t}-T_{\text {base }} & \text { if } T_{t}>T_{\text {opt }}\end{array}\right\}\end{array}$ \\
\hline $\begin{array}{l}\text { Days above the optimal and } \\
\text { threshold temperatures }\end{array}$ & $\begin{array}{l}\text { 2009-10, } \\
2011-12\end{array}$ & NASA & $\begin{array}{l}\text { (i) Number of days in the growing period for the major crop in the district when } \\
T_{t}>T_{\text {opt }} \\
\text { (ii)Number of days in the growing period for the major crop in the district when } \\
T_{t}>T_{\text {high }}\end{array}$ \\
\hline $\begin{array}{l}\text { Absolute positive deviation in } \\
\text { rainfall (APD) } \\
\text { Absolute negative deviation } \\
\text { in rainfall (AND) }\end{array}$ & $\begin{array}{l}\text { 2009-10, } \\
2011-12\end{array}$ & $\begin{array}{l}\text { NASA, Tropical Rainfall } \\
\text { Measuring Mission Project } \\
\text { http://mirador.gsfc.nasa.gov/collecti } \\
\text { ons/TRMM 3B43 007.shtml }\end{array}$ & $\begin{array}{l}\text { A rainfall index for each month was obtained by calculating the deviation of } \\
\text { that month's rainfall from the mean divided by the standard deviation for that } \\
\text { month over the period } 2001-12 \text {. } \\
\text { Then the rainfall variables are calculated by summing the positive and the } \\
\text { negative rainfall indices separately. } A P D_{j}=\Sigma P R I_{k j} ; A N D_{j}=\Sigma N R I_{k j} \\
\text { where } P R I_{k j}=\text { sum of } R I \text { of all the months (indexed by k) for a district if the } \\
\text { rainfall indices are positive } \\
\text { and } N R I_{k j}=\text { sum of } R I \text { of all the months (indexed by k) for a district if the } \\
\text { rainfall indices are negative } \\
\text { Here } R I_{k}=(\text { Mean of rainfall for } k t h \text { month from } 2001 \text { to 2012)/standard } \\
\text { deviation }\end{array}$ \\
\hline
\end{tabular}

Source: Narayanan, et al (2017); For details of crop and thresholds, see supplementary materials associated with Narayanan, et al. (2017) 


\section{Appendix B: IV Results}

Table B.1: Instrument validity tests for all IV Models in Table 3 NDVI as instrument

\begin{tabular}{|c|c|c|c|c|c|c|c|c|}
\hline \multicolumn{9}{|c|}{ Tests for identification in the IV model using NDVI } \\
\hline \multirow{2}{*}{$\begin{array}{l}\text { Dependent variable } \\
\text { Two square meals }(=1)\end{array}$} & \multicolumn{2}{|c|}{ Endogeneity } & \multicolumn{2}{|c|}{$\begin{array}{l}\text { Anderson-Rubin F-test of } \\
\text { significance of endogenous } \\
\text { regressors }\end{array}$} & \multicolumn{2}{|c|}{$\begin{array}{c}\text { Anderson-Rubin chi-sq test } \\
\text { of significance of } \\
\text { endogenous regressors }\end{array}$} & \multicolumn{2}{|c|}{ Stock Wright statistic } \\
\hline & 0.407 & 0.5233 & 0.4 & 0.5284 & 0.4 & 0.5283 & 0.41 & 0.5236 \\
\hline Three meals $(=1)$ & 83.051 & 0.00 & 82.96 & 0.00 & 82.97 & 0.00 & 84.28 & 0.00 \\
\hline Household dietary diversity score $(\log )$ & & & 61.27 & 0.08 & 122.55 & 0.00 & & \\
\hline Household dietary diversity score (past month) & 42.11 & 0.00 & 52.38 & 0.00 & 52.48 & 0.00 & 70.68 & 0.00 \\
\hline \multicolumn{9}{|c|}{ Whether this foodgroup is consumed (exclude cereal consumption due to small number who do not) } \\
\hline Cereal consumption $(1=\mathrm{Yes})$ & . & & 8.77 & 0.00 & 8.79 & 0.00 & 464.76 & 0.00 \\
\hline Roots and Tubers consumption ( $1=$ Yes) & 0.92 & 0.34 & 0.91 & 0.34 & 0.91 & 0.34 & 1.91 & 0.17 \\
\hline Vegetables consumption $(1=$ Yes $)$ & 0.66 & 0.42 & 19.33 & 0.00 & 19.37 & 0.00 & 0.65 & 0.42 \\
\hline Green leafy vegetables $(1=$ Yes $)$ & 2.91 & 0.09 & 3.35 & 0.07 & 3.36 & 0.07 & 5.94 & 0.01 \\
\hline Fruits consumption $(1=$ Yes $)$ & 22.40 & 0.00 & 42.43 & 0.00 & 42.51 & 0.00 & 38.44 & 0.00 \\
\hline Meat and eggs $(1=$ Yes $)$ & 57.19 & 0.00 & 72.78 & 0.00 & 72.92 & 0.00 & 89.71 & 0.00 \\
\hline Fish and seafood consumption ( $1=$ Yes $)$ & 65.99 & 0.00 & 100.83 & 0.00 & 101.03 & 0.00 & 142.89 & 0.00 \\
\hline Pulses/legumes/nuts $(1=$ Yes $)$ & 5.29 & 0.02 & 38.02 & 0.00 & 38.09 & 0.00 & 10.42 & 0.00 \\
\hline $\operatorname{Milk}(1=$ Yes $)$ & 20.44 & 0.00 & 32.22 & 0.00 & 32.28 & 0.00 & 37.37 & 0.00 \\
\hline Oils $(1=$ Yes $)$ & 2.42 & 0.12 & 7.75 & 0.01 & 7.77 & 0.01 & 6.58 & 0.01 \\
\hline Sugar/honey (1=Yes) & 2.88 & 0.09 & 5.43 & 0.02 & 5.44 & 0.02 & 7.15 & 0.01 \\
\hline Miscellaneous (1=Yes) & 0.13 & 0.71 & 1.46 & 0.23 & 1.47 & 0.23 & 0.24 & 0.62 \\
\hline
\end{tabular}


Within food group diversity (excludes three groups that have only one item)

\begin{tabular}{|c|c|c|c|c|c|c|c|c|}
\hline Cereals diversity & 8.22 & 0.00 & 150.36 & 0.00 & 150.65 & 0.00 & 19.05 & 0.00 \\
\hline Vegetables & 17.25 & 0.00 & 0.42 & 0.52 & 0.42 & 0.52 & 33.94 & 0.00 \\
\hline Fruits & 35.64 & 0.00 & 24.02 & 0.00 & 24.07 & 0.00 & 68.11 & 0.00 \\
\hline Meat, poultry, offal F. Eggs & 58.39 & 0.00 & 72.46 & 0.00 & 72.60 & 0.00 & 96.26 & 0.00 \\
\hline Pulses/legumes/nuts & 30.39 & 0.00 & 5.68 & 0.02 & 5.69 & 0.02 & 62.79 & 0.00 \\
\hline Milk and milk products & 27.74 & 0.00 & 23.58 & 0.00 & 23.62 & 0.00 & 43.62 & 0.00 \\
\hline Oil/fats & 7.86 & 0.01 & 2.52 & 0.11 & 2.52 & 0.11 & 13.11 & 0.00 \\
\hline Sugar/honey & 5.29 & 0.02 & 3.16 & 0.08 & 3.17 & 0.08 & 11.55 & 0.00 \\
\hline Miscellaneous & 1.42 & 0.23 & 0.16 & 0.69 & 0.16 & 0.69 & 2.25 & 0.13 \\
\hline
\end{tabular}


Table B.2: First stage results for Free Collection

Dependent variable: Free collection household (=1)

\begin{tabular}{lc}
\hline Covariates & $\begin{array}{c}\text { NDVI } \\
\text { b/se }\end{array}$ \\
\hline NDVI & $0.0000^{* * *}$ \\
Hindu (=1) & $-0.0130^{* * *}$ \\
Scheduled Castes/Tribes $=1$ & $0.0412^{* * *}$ \\
Dependency ratio & $-0.0002^{* * *}$ \\
Female-headed household & $-0.0069^{* *}$ \\
Age of the head of the household & $-0.0002^{* * *}$ \\
Number of members completed primary education & $-0.0062^{* * *}$ \\
Number of members completed higher secondary & \\
education & $-0.0031^{* * *}$ \\
Computed household size & $0.0032^{* * *}$ \\
Most educated member has completed primary school & $-0.0127^{* *}$ \\
Owned any Land & $0.0101^{* *}$ \\
Total Land possessed & -0.0001 \\
Casual worker-household (=1) & 0.0079 \\
MPCE & $-0.0000^{* * *}$ \\
Growing degree days & 0 \\
Days below the minimum threshold & -0.0001 \\
Days above the maximum threshold & $-0.0002^{* *}$ \\
Rainfall shock & $-0.0050^{* * *}$ \\
Lean season (June to October) & $-0.0054^{* *}$ \\
Rainfall surplus & $0.0023^{* * *}$ \\
Home production & $-0.0124^{* * *}$ \\
Market purchases & $-0.0120^{* * *}$ \\
Home production and market purchases & $-0.0107^{* * *}$ \\
Household food price index & 0 \\
District food price index & 0 \\
District share of food consumption from the market & $-0.0007^{*}$ \\
Sector & $0.0282^{* * *}$ \\
Round=68 & 0.0038 \\
Free collection district (LQ $>1)=1$ & $0.0839^{* * *}$ \\
Constant & $1.2950^{* * *}$ \\
\hline $\mathbf{N}$ & $\mathbf{1 7 0 8 9 6}$ \\
\hline & \\
& \\
&
\end{tabular}


Figure B.1: NDVI by Free collection status.

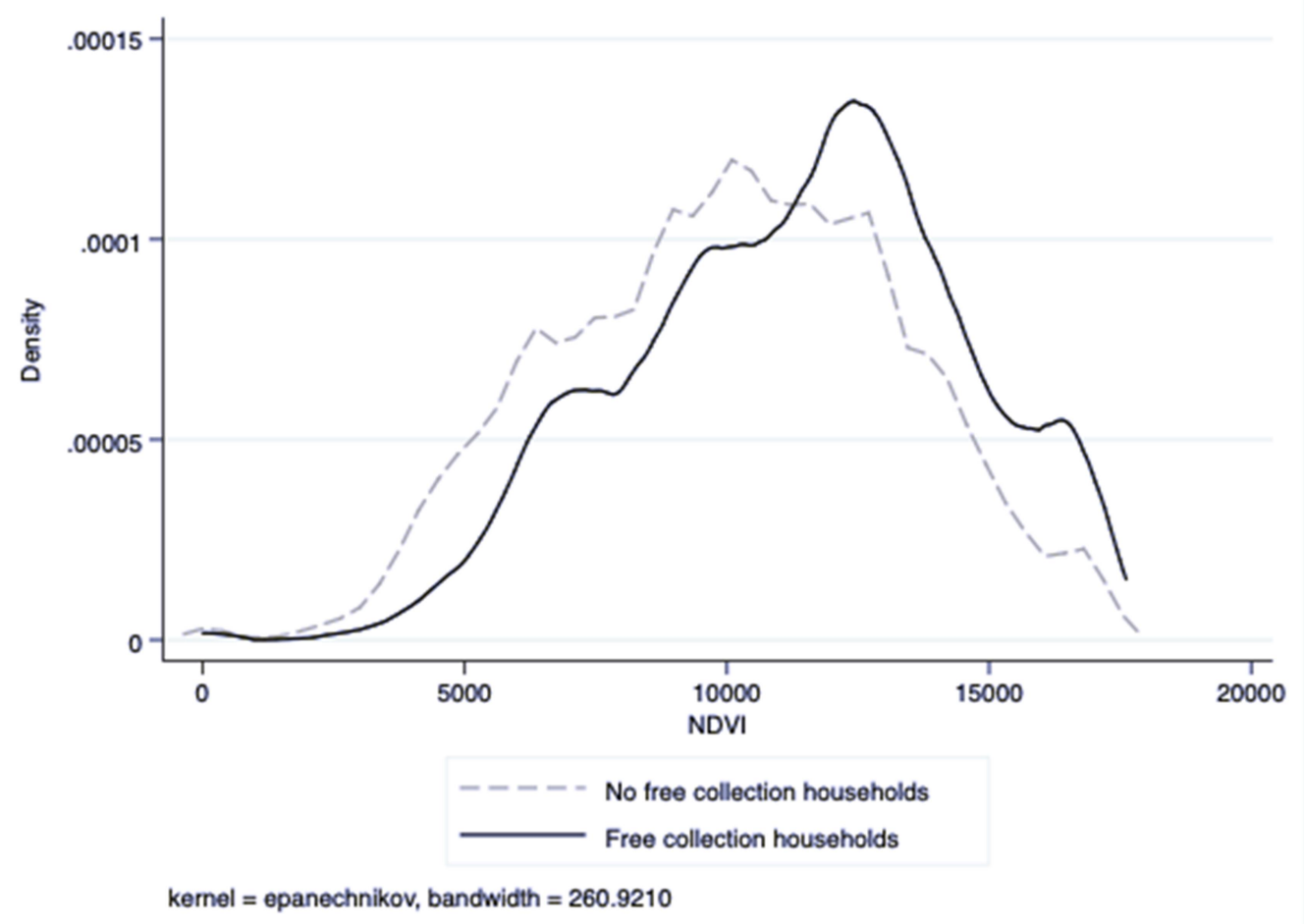




\section{Appendix C: Endogenizing shares from own production and market}

Note: 0 values represent very negligible values.

\begin{tabular}{|c|c|c|c|c|c|}
\hline \multirow{2}{*}{$\begin{array}{c}\text { Dependent variable: } \\
\ln (\text { HDDS })\end{array}$} & \multirow[t]{2}{*}{ Second Stage } & \multicolumn{4}{|c|}{ First stage regression } \\
\hline & & Free collection & $\begin{array}{c}\text { Share from } \\
\text { market }\end{array}$ & $\begin{array}{c}\text { Share from own } \\
\text { production }\end{array}$ & $\begin{array}{c}\text { own } \\
\text { production } \\
\text { and market }\end{array}$ \\
\hline \multirow{2}{*}{$\begin{array}{l}\text { Free collection } \\
\text { household }\end{array}$} & $1.7289 * *$ & & & & \\
\hline & -0.7194 & & & & \\
\hline \multirow[t]{2}{*}{ Home production } & $0.0629 * * *$ & & & & \\
\hline & $(0.02)$ & & & & \\
\hline \multirow[t]{2}{*}{ Market purchases } & $0.0516^{* *}$ & & & & \\
\hline & $(0.02)$ & & & & \\
\hline \multirow{2}{*}{$\begin{array}{l}\text { Home production and } \\
\text { market purchases }\end{array}$} & $0.0671^{* *}$ & & & & \\
\hline & $(0.03)$ & & & & \\
\hline \multirow[t]{2}{*}{ NDVI } & & $0.0000^{* * *}$ & -0.0002 & 0 & $0.0001 * * *$ \\
\hline & & 0.00 & $(0.00)$ & $(0.00)$ & 0.00 \\
\hline \multirow[t]{2}{*}{ Growing degree days } & & 0 & $0.0003 * * *$ & $-0.0004 * * *$ & $0.0001^{*}$ \\
\hline & & 0.00 & $(0.00)$ & $(0.00)$ & 0.00 \\
\hline \multirow{2}{*}{$\begin{array}{l}\text { Days below the } \\
\text { temperature threshold }\end{array}$} & & 0 & -0.0062 & 0.0044 & 0.0007 \\
\hline & & $(0.00)$ & $(0.01)$ & $(0.01)$ & $(0.00)$ \\
\hline \multirow{2}{*}{$\begin{array}{l}\text { Days over the } \\
\text { temperature threshold }\end{array}$} & & $-0.0002 * * *$ & $-0.0132 *$ & $0.0220 * * *$ & $-0.0067 * * *$ \\
\hline & & $(0.00)$ & $(0.01)$ & $(0.01)$ & $(0.00)$ \\
\hline \multirow{2}{*}{$\begin{array}{l}\text { Rainfall shock } \\
\text { (negative deviation) }\end{array}$} & & $-0.0056^{* * *}$ & 0.0786 & 0.0389 & -0.0742 \\
\hline & & $(0.00)$ & $(0.17)$ & $(0.21)$ & $(0.05)$ \\
\hline \multirow{3}{*}{$\begin{array}{l}\text { Lean season (June to } \\
\text { October) }\end{array}$} & & $-0.0049 *$ & -0.0378 & 0.0576 & -0.0629 \\
\hline & & $(0.00)$ & $(0.26)$ & $(0.26)$ & $(0.06)$ \\
\hline & & 0.0018 & 0.1393 & -0.0828 & -0.0189 \\
\hline Rainfall surplus & & $(0.00)$ & $(0.09)$ & $(0.10)$ & $(0.03)$ \\
\hline \multirow{2}{*}{$\begin{array}{l}\text { Household food price } \\
\text { index }\end{array}$} & & 0 & $0.0004 * * *$ & $-0.0005 * * *$ & 0 \\
\hline & & 0.00 & $(0.00)$ & $(0.00)$ & 0.00 \\
\hline \multirow{2}{*}{$\begin{array}{l}\text { District food price } \\
\text { index }\end{array}$} & & 0 & $0.0026^{*}$ & $-0.0030 *$ & $-0.0003 * *$ \\
\hline & & 0.00 & $(0.00)$ & $(0.00)$ & $(0.00)$ \\
\hline \multirow{3}{*}{$\begin{array}{l}\text { District share from } \\
\text { market }\end{array}$} & & $-0.0015 * * *$ & $0.5563 * * *$ & $-0.4932 * * *$ & $-0.0222 * * *$ \\
\hline & & $(0.00)$ & $(0.04)$ & $(0.04)$ & $(0.01)$ \\
\hline & 0.0141 & $-0.0143^{* *}$ & -0.5006 & 1.0986 & $-0.5312 * * *$ \\
\hline Hindu $(=1)$ & $(0.01)$ & $(0.01)$ & $(0.73)$ & $(0.71)$ & $(0.18)$ \\
\hline Scheduled & $-0.0773 * * *$ & $0.0442 * * *$ & 0.5816 & $-1.2798 * *$ & $0.4780 * * *$ \\
\hline Castes/Tribes $=1$ & $(0.02)$ & $(0.01)$ & $(0.55)$ & $(0.53)$ & $(0.13)$ \\
\hline \multirow[t]{2}{*}{ Dependency ratio } & $0.0005^{*}$ & $-0.0001 *$ & $0.0168 * * *$ & $-0.0261 * * *$ & -0.0012 \\
\hline & $(0.00)$ & 0.00 & $(0.00)$ & $(0.00)$ & $(0.00)$ \\
\hline \multirow[t]{2}{*}{$\begin{array}{l}\text { Female-headed } \\
\text { household }\end{array}$} & 0.0076 & -0.002 & $1.1859 * * *$ & $-1.6117 * * *$ & -0.0249 \\
\hline & $(0.01)$ & $(0.00)$ & $(0.24)$ & $(0.24)$ & $(0.05)$ \\
\hline \multirow{2}{*}{$\begin{array}{l}\text { Age of the head of the } \\
\text { household }\end{array}$} & & & & & \\
\hline & $\begin{array}{c}0.0009^{* *} \\
(0.00)\end{array}$ & $\begin{array}{c}-0.0001^{* *} \\
(0.00)\end{array}$ & $\begin{array}{c}-0.0753 \\
(0.01)\end{array}$ & $\begin{array}{c}0.0700 \\
(0.01)\end{array}$ & $\begin{array}{c}0.0065 \\
(0.00)\end{array}$ \\
\hline
\end{tabular}




\begin{tabular}{|c|c|c|c|c|c|}
\hline \multirow{3}{*}{$\begin{array}{l}\text { Number of members } \\
\text { completed primary } \\
\text { education } \\
\text { Number of members } \\
\text { completed higher } \\
\text { secondary education }\end{array}$} & $0.0162 * *$ & $-0.0061 * * *$ & $-0.3829 * *$ & $0.2609 *$ & $0.1419 * * *$ \\
\hline & -0.0046 & $-0.0049 * * *$ & $0.8911 * * *$ & $-0.6286 * * *$ & $-0.1546^{* * *}$ \\
\hline & $(0.00)$ & $(0.00)$ & $(0.14)$ & $(0.14)$ & $(0.04)$ \\
\hline \multirow{4}{*}{$\begin{array}{l}\text { Household size } \\
\text { Highest educated } \\
\text { member has completed } \\
\text { primary school }\end{array}$} & $0.0090 * *$ & $0.0035^{* * *}$ & $-1.3689 * * *$ & $1.2954 * * *$ & $0.1062 * * *$ \\
\hline & $(0.00)$ & $(0.00)$ & $(0.13)$ & $(0.12)$ & $(0.02)$ \\
\hline & $0.0516^{* *}$ & $-0.0192 * * *$ & $-1.2562 * * *$ & $1.6805^{* * *}$ & $0.1762 * * *$ \\
\hline & $(0.03)$ & $(0.01)$ & $(0.43)$ & $(0.35)$ & $(0.06)$ \\
\hline \multirow{3}{*}{ Owned any Land } & -0.0197 & 0.0029 & -0.6997 & $1.2176^{* *}$ & $0.1177^{*}$ \\
\hline & $(0.02)$ & $(0.00)$ & $(0.59)$ & $(0.50)$ & $(0.06)$ \\
\hline & $0.0020 * * *$ & -0.0001 & $-0.1850 * * *$ & $0.1741^{* * *}$ & $0.0150 * * *$ \\
\hline Total Land possessed & $(0.00)$ & 0.00 & $(0.01)$ & $(0.01)$ & $(0.00)$ \\
\hline \multirow{3}{*}{$\begin{array}{l}\text { Casual worker- } \\
\text { household }(=1)\end{array}$} & $-0.0858 * * *$ & $0.0090 * * *$ & $7.3619^{* * *}$ & $-7.5339 * * *$ & $-0.1760 * * *$ \\
\hline & $(0.02)$ & $(0.00)$ & $(0.46)$ & $(0.46)$ & $(0.05)$ \\
\hline & $0.0002 * * *$ & $-0.0000 * * *$ & $-0.0074 * * *$ & $0.0080^{* * *}$ & 0.0002 \\
\hline \multirow[t]{2}{*}{ MPCE } & 0.00 & 0.00 & $(0.00)$ & $(0.00)$ & $(0.00)$ \\
\hline & $0.1027 * * *$ & $0.0400 * * *$ & $-13.1126^{* * *}$ & $11.9839 * * *$ & $0.6499 * * *$ \\
\hline Rural & $(0.02)$ & $(0.00)$ & $(0.96)$ & $(0.92)$ & $(0.09)$ \\
\hline \multirow[t]{2}{*}{ Round $=68$} & $-0.1301 * * *$ & -0.0066 & $11.1477 * * *$ & $-10.0245 * * *$ & $-0.6969 * * *$ \\
\hline & $(0.02)$ & $(0.00)$ & $(0.60)$ & $(0.60)$ & $(0.08)$ \\
\hline \multirow{2}{*}{$\begin{array}{l}\text { Free collection district } \\
(\mathrm{LQ}>=1)=1\end{array}$} & -0.08 & $0.0962 * * *$ & $-1.4032 * *$ & -0.0938 & $0.5843 * * *$ \\
\hline & $(0.06)$ & $(0.01)$ & $(0.55)$ & $(0.58)$ & $(0.17)$ \\
\hline \multirow[t]{2}{*}{ Constant } & $-4.0469 * *$ & $0.1219 * * *$ & $61.1938 * * *$ & $34.2124 * * *$ & 0.3125 \\
\hline & $(1.97)$ & $(0.03)$ & $(2.78)$ & (3.06) & $(0.43)$ \\
\hline $\begin{array}{l}\text { Number of } \\
\text { observations }\end{array}$ & 170896 & 170896 & 170896 & 170896 & 170896 \\
\hline $\mathrm{F}$ & 16.13 & & & & \\
\hline $\mathrm{j}$ & 8.03 & & & & \\
\hline jp & 0.24 & & & & \\
\hline idstat & 10.1 & & & & \\
\hline idp & 0.18 & & & & \\
\hline widstat & 0.90 & & & & \\
\hline \multirow{2}{*}{$\begin{array}{l}\text { Anderson-Rubin F-test } \\
\text { of significance of } \\
\text { endogenous regressors }\end{array}$} & 58.10 & & & & \\
\hline & 0.00 & & & & \\
\hline \multirow{2}{*}{$\begin{array}{l}\text { Anderson-Rubin chi-sq } \\
\text { test of significance of } \\
\text { endogenous regressors }\end{array}$} & 588.72 & & & & \\
\hline & 0.00 & & & & \\
\hline \multirow{2}{*}{ Endogeneity Test } & 8.66 & & & & \\
\hline & 0.003 & & & & \\
\hline \multirow{2}{*}{$\begin{array}{l}\text { Stock-Wright S- } \\
\text { statistic }\end{array}$} & 62.2 & & & & \\
\hline & 0.00 & & & & \\
\hline
\end{tabular}




\section{Appendix D: Propensity Score Matching Results}

The quality of match is verified using the reduction in standardized bias for each covariate

Figure D.1: The distribution of statndardized bias in covariates, before and after matching
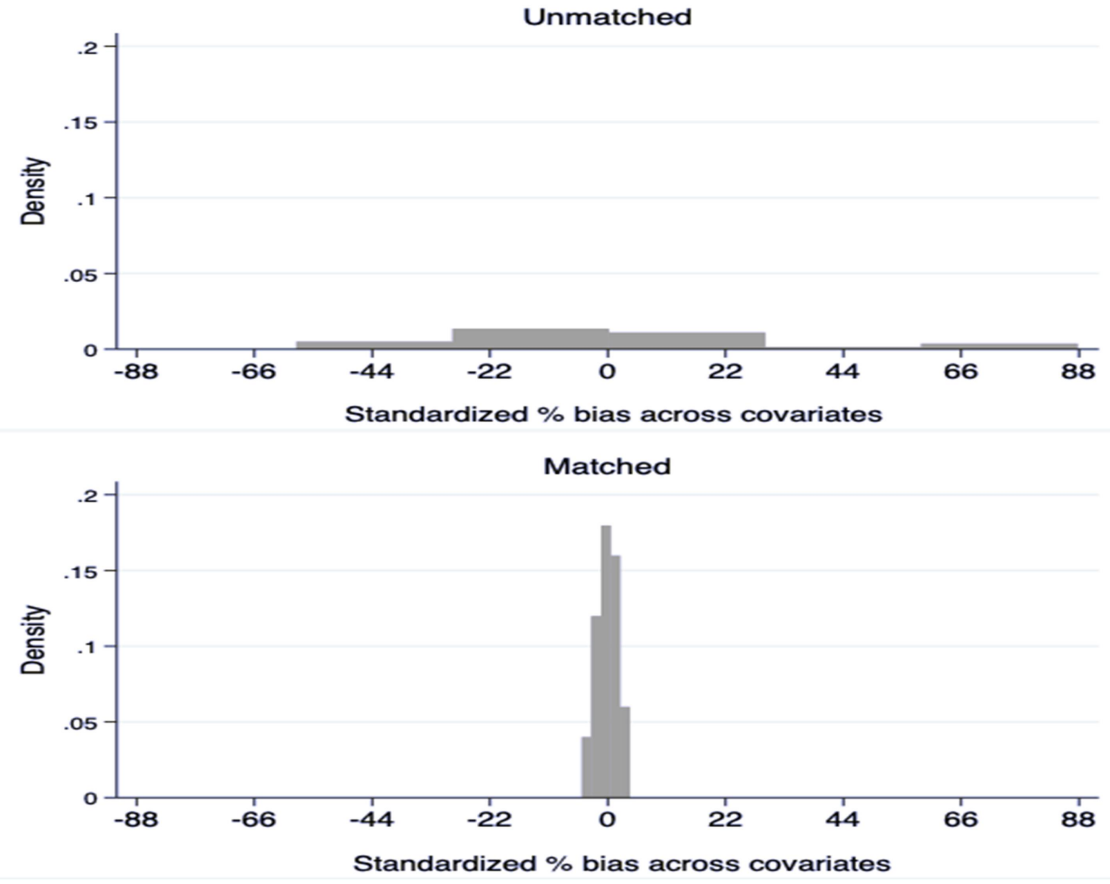

Figure D.2 Covariate-wise reduction in bias after matching

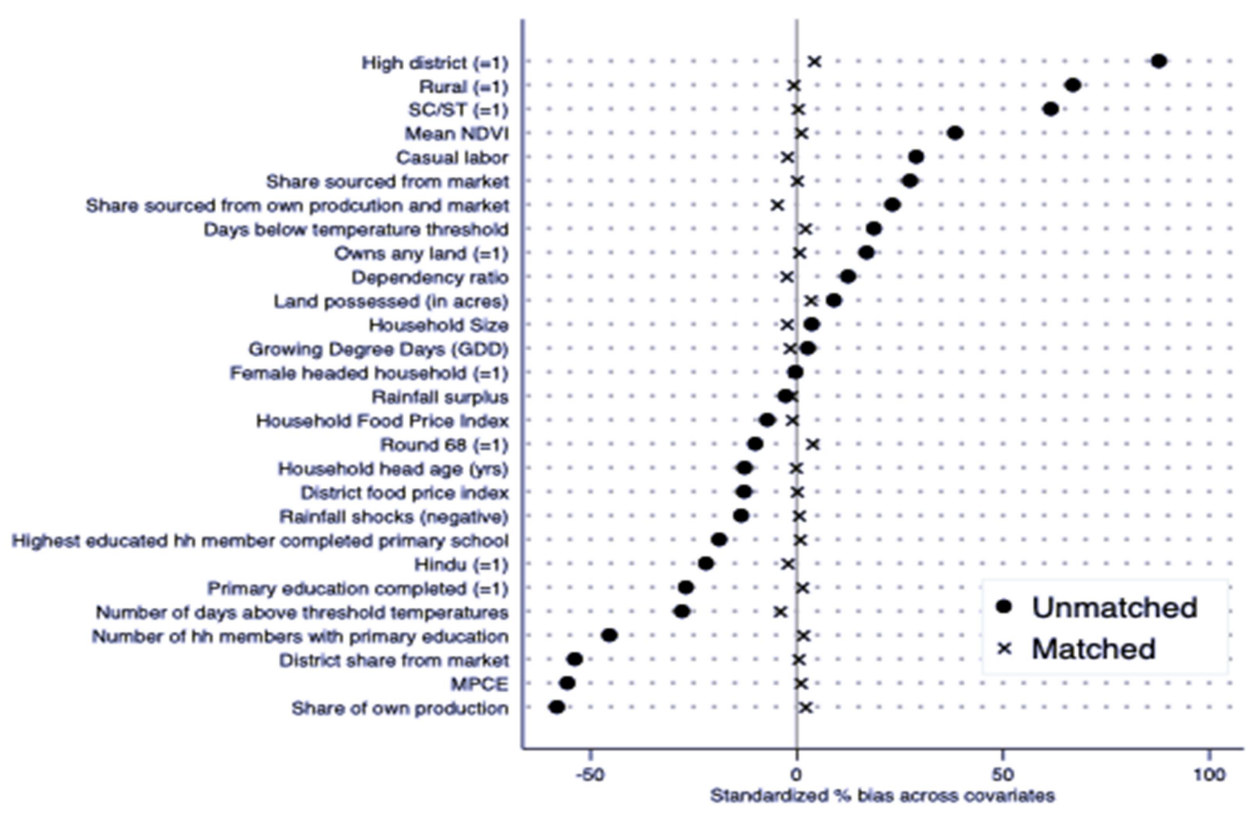


Table D.1: Average Treatment effects on the Treated: Results from Propensity Score Matching

\begin{tabular}{|c|c|c|c|c|c|c|c|c|c|c|c|c|c|}
\hline \multirow[b]{2}{*}{ Variable } & \multicolumn{13}{|c|}{ PSM with Abadie-Imbens Standard } \\
\hline & Treated & Controls & ATT & S.E. & T-stat & ATT & S.E & Z -stat & $\begin{array}{l}P \text { - } \\
\text { value }\end{array}$ & ATT & $\begin{array}{l}\text { AI } \\
\text { Standard } \\
\text { errors } \\
\end{array}$ & $\begin{array}{l}\mathrm{Z} \\
\text { statistic }\end{array}$ & P-value \\
\hline HDDS & 10.36 & 10.09 & 0.27 & 0.02 & 15.02 & 0.2688 & 0.0169 & 15.93 & 0 & & & & \\
\hline Cereals & 4.23 & 4.23 & 0.00 & 0.02 & 0.02 & 0.001 & 0.018 & 0.04 & 0.967 & $2.07 \mathrm{e}$ & $2.03 \mathrm{e}$ & 102.03 & 0 \\
\hline Roots and tubers & 0.94 & 0.94 & 0.00 & 0.00 & 1.72 & 0.005 & 0.003 & 1.68 & 0.092 & 0.0055 & 0.0032 & 1.68 & 0.092 \\
\hline $\begin{array}{l}\text { Vegetables } \\
\text { Green leafy }\end{array}$ & 6.86 & 6.87 & -0.01 & 0.03 & -0.33 & -0.012 & 0.028 & -0.42 & 0.676 & 0.0052 & 0.0010 & 5.38 & 0 \\
\hline vegetables & 0.84 & 0.75 & 0.09 & 0.01 & 17.44 & 0.090 & 0.005 & 18.1 & 0 & 0.0900 & 0.0050 & 18.1 & 0 \\
\hline Furits & 1.57 & 1.45 & 0.12 & 0.02 & 6.44 & 0.117 & 0.016 & 7.45 & 0 & 0.0414 & 0.0055 & 7.5 & 0 \\
\hline Meats, eggs & 1.29 & 1.16 & 0.13 & 0.01 & 8.94 & 0.128 & 0.012 & 10.64 & 0 & 0.0341 & 0.0055 & 6.17 & 0 \\
\hline Fish & 0.61 & 0.48 & 0.13 & 0.01 & 20.84 & 0.134 & 0.006 & 22.21 & 0 & 0.1339 & 0.0060 & 22.21 & 0 \\
\hline Pulses & 3.84 & 3.98 & -0.14 & 0.03 & -5.61 & -0.141 & 0.021 & -6.65 & 0 & 0.0015 & 0.0027 & 0.55 & 0.583 \\
\hline Milk & 1.45 & 1.53 & -0.08 & 0.01 & -5.67 & -0.083 & 0.013 & -6.24 & 0 & -0.0422 & 0.0056 & -7.5 & 0 \\
\hline Oils & 2.19 & 2.18 & 0.02 & 0.01 & 2.23 & 0.017 & 0.008 & 2.22 & 0.026 & 0.0030 & 0.0023 & 1.28 & 0.199 \\
\hline Sugar & 1.31 & 1.29 & 0.02 & 0.01 & 1.96 & 0.016 & 0.008 & 2.1 & 0.036 & -0.0028 & 0.0029 & -0.98 & 0.329 \\
\hline Miscellaneous & 3.93 & 3.88 & 0.05 & 0.03 & 1.77 & 0.044 & 0.026 & 1.72 & 0.086 & -0.0005 & 0.0018 & -0.3 & 0.766 \\
\hline
\end{tabular}




\section{Appendix E: Triple /Quadruple Difference Estimates}

$$
\begin{aligned}
& \ln \left(H D D S_{h d r}\right)=\beta_{0} \\
& +\beta_{1} F_{h d r}+\beta_{2} \text { Lean }_{h d r}+\beta_{3} H i g h_{h d r} \\
& +\beta_{4} F_{h d r} \times L_{L a n_{h d r}}+\beta_{5} F_{h d r} \times H i g h_{h d r}+\beta_{6} L_{e a n_{h d r}} \times H i g h_{h d r} \\
& +\beta_{5} F_{h d r} \times H_{i g h} \text { hdr } \times \text { Lean }_{h d r}++\alpha_{2} H_{h d r}+\alpha_{3} \text { Lean }_{d r}+\alpha_{4} \sum_{j=1}^{3} \text { Temp }_{j h d r} \\
& +\alpha_{5} \sum_{k=1}^{2} R F_{k h d r}+\alpha_{6} \text { Rural }_{h d r}+\alpha_{7} \text { NSS Round } \text { Rr }+\alpha_{8} \text { High }+\varepsilon \\
& \ln \left(H D D S_{h d r}\right)=\beta_{0} \\
& +\beta_{1} F_{h d r}+\beta_{2} \text { Lean }_{h d r}+\beta_{3} \text { High }_{h d r}+\beta_{3} \text { High }_{h d r}+\delta_{1} \text { Rural } \\
& +\beta_{4} F_{h d r} \times \operatorname{Lean}_{h d r}+\beta_{5} F_{h d} \times H i g h_{h d r}+\beta_{6} \text { Lean }_{h d} \times H i g h_{h d r} \\
& +\delta_{2} \text { Rural } \times F_{h d r}+\delta_{3} \text { Rural } \times H i g h_{h d r}+\delta_{4} \text { Rural } \times \text { Lean }_{h d r} \\
& +\delta_{5} \text { Rural } \times \text { Lean }_{h d r} \times H_{i g h}{ }_{h d}+\delta_{6} \text { Rural } \times F_{h d r} \times H i g h_{h d r}+\beta_{5} F_{h d r} \\
& \times \mathrm{High}_{h d r} \times \operatorname{Lean}_{h d r}+\delta_{6} \text { Rural } \times F_{h d r} \times H i g h_{h d r} \times \operatorname{Lean}_{h d r} \\
& +\alpha_{2} H_{h d r}+\alpha_{3} \text { Lean }_{d r}+\alpha_{4} \sum_{j=1}^{3} \text { Temp }_{j h d r}+\alpha_{5} \sum_{k=1}^{2} R F_{k h d r}+\alpha_{6} \text { Rural }_{h d r} \\
& +\alpha_{7} \text { NSS Round } d r+\alpha_{8} H i g h+\varepsilon(6)
\end{aligned}
$$




\begin{tabular}{|c|c|c|}
\hline Dependent variable $=\ln ($ HDDS $)$ & $\begin{array}{c}\text { Triple } \\
\text { Difference } \\
\text { b/se }\end{array}$ & $\begin{array}{l}\text { Quadruple Difference } \\
\text { b/se }\end{array}$ \\
\hline Free collection household=1 & $\begin{array}{l}0.0088^{* * *} \\
0.00\end{array}$ & $\begin{array}{l}0.0136^{* *} \\
(0.01)\end{array}$ \\
\hline Lean season $($ June to October $)=1$ & $\begin{array}{c}-0.0133 * * * \\
0.00\end{array}$ & $\begin{array}{l}-0.0115^{* * * *} \\
0.00\end{array}$ \\
\hline Round $=68$ & $\begin{array}{l}0.0086^{* * *} \\
0.00\end{array}$ & $\begin{array}{l}0.0086^{* * *} \\
0.00\end{array}$ \\
\hline Rural & $\begin{array}{l}0.0044^{* * *} \\
0.00\end{array}$ & $\begin{array}{l}0.0080^{* * *} \\
0.00\end{array}$ \\
\hline Free collection district $(\mathrm{LQ}>=1)=1$ & $\begin{array}{l}0.0138^{* * *} \\
0.00\end{array}$ & $\begin{array}{l}0.0225^{* * *} \\
0.00\end{array}$ \\
\hline $\begin{array}{l}\text { Free collection household=1 \# Lean season (June to } \\
\text { October) }=1\end{array}$ & $\begin{array}{c}-0.0048 \\
0.00\end{array}$ & $\begin{array}{c}-0.0056 \\
(0.01)\end{array}$ \\
\hline $\begin{array}{l}\text { Free collection household }=1 \text { \# Free collection district } \\
(\mathrm{LQ}>=1)=1\end{array}$ & $\begin{array}{c}-0.0003 \\
(0.01)\end{array}$ & $\begin{array}{l}0.0142 \\
(0.01)\end{array}$ \\
\hline $\begin{array}{l}\text { Lean season }(\text { June to October })=1 \text { \# Free collection } \\
\text { district }(L Q>=1)=1\end{array}$ & $\begin{array}{c}0.0056^{*} \\
0.00\end{array}$ & $\begin{array}{l}0.001 \\
(0.01)\end{array}$ \\
\hline Free collection district $(\mathrm{LQ}>=1)=1 \#$ Rural & & $\begin{array}{c}-0.0139 * * * \\
0.00\end{array}$ \\
\hline Free collection household=1 \# Rural & & $\begin{array}{c}-0.0067 \\
(0.01)\end{array}$ \\
\hline Lean season (June to October) $=1$ \# Rural & & $\begin{array}{c}-0.003 \\
0.00\end{array}$ \\
\hline $\begin{array}{l}\text { Free collection household }=1 \text { \# Lean season }(\text { June to } \\
\text { October })=1 \text { \# Free collection district }(\mathrm{LQ}>=1)=1\end{array}$ & $\begin{array}{l}0.002 \\
(0.01)\end{array}$ & $\begin{array}{c}-0.0154 \\
(0.02)\end{array}$ \\
\hline $\begin{array}{l}\text { Free collection household=1 \# Lean season (June to } \\
\text { October) }=1 \text { \# Rural }\end{array}$ & & $\begin{array}{r}0.0017 \\
(0.01)\end{array}$ \\
\hline $\begin{array}{l}\text { Free collection household=1 \# Free collection district } \\
(\mathrm{LQ}>=1)=1 \text { \# Rural }\end{array}$ & & $\begin{array}{c}-0.0122 \\
(0.01)\end{array}$ \\
\hline $\begin{array}{l}\text { Free collection household=1 \# Lean season (June to } \\
\text { October)=1 \# Free collection district (LQ>=1)=1 \# Rural }\end{array}$ & & 0.0176 \\
\hline
\end{tabular}

Full results are available from the author. 0 standard errors represent very small values and are hence not fully presented here. 
